\title{
Cultural Resources Survey of the Lone Star Express II Pipeline - Loop 3, in Eastland, Comanche, Erath, and Bosque Counties,
}

\section{Texas}

Tony Scott

Amanda Kloepfer

Follow this and additional works at: https://scholarworks.sfasu.edu/ita

Part of the American Material Culture Commons, Archaeological Anthropology Commons, Environmental Studies Commons, Other American Studies Commons, Other Arts and Humanities Commons, Other History of Art, Architecture, and Archaeology Commons, and the United States History Commons

Tell us how this article helped you.

This Article is brought to you for free and open access by the Center for Regional Heritage Research at SFA ScholarWorks. It has been accepted for inclusion in Index of Texas Archaeology: Open Access Gray Literature from the Lone Star State by an authorized editor of SFA ScholarWorks. For more information, please contact cdsscholarworks@sfasu.edu. 
Cultural Resources Survey of the Lone Star Express II Pipeline - Loop 3, in Eastland, Comanche, Erath, and Bosque Counties, Texas

\section{Creative Commons License}

\section{(c) (1) \&}

This work is licensed under a Creative Commons Attribution-NonCommercial 4.0 International License 


\section{GRAY $\&$ PAPE HERITAGE MANAGEMENT}

Cultural Resources Survey of the Lone Star Express II Pipeline Loop 3, in Eastland, Comanche, Erath, and Bosque Counties, Texas

Lead Agency:

The United States Army Corps of Engineers, Fort Worth District

SWF-2019-00091

PREPARED FDR:

EDGE Engineering \& Science LLC 16285 Park Ten Place, Suite 400

Houston, Texas 77084

\section{PREPARED BY:} Gray \& Pape, Inc. 110 Avondale Street Houston, Texas 77006 


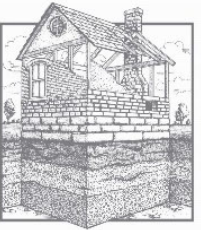

\section{GRAY $\circlearrowleft$ PAPE \\ HERITAGE MANAGEMENT}

Project No. 19-71601.001

Cultural Resources Survey of the Lone Star Express II Pipeline - Loop 3, in Eastland, Comanche, Erath, and Bosque Counties, Texas

Lead Agency:

The United States Army Corps of Engineers, Fort Worth District

Prepared for:

EDGE Engineering \& Science

16285 Park Ten Place, Suite 400

Houston, Texas 77084

Kristi Soltysiak

Prepared by:

Tony Scott

And

Amanda Kleopfer

Gray \& Pape, Inc.

110 Avondale Street

Houston, Texas 77006

(713) 541-0473

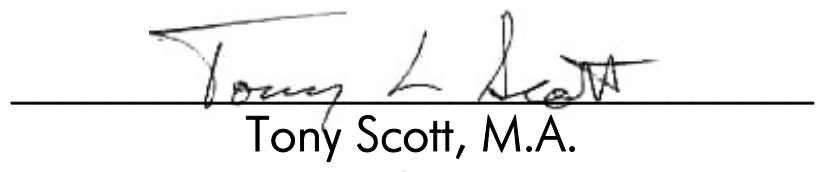

Sr. Principal Investigator

February 13, 2020 


\section{ABSTRACT}

Gray \& Pape, Inc., of Houston, Texas, on behalf of Lone Star NGL Pipeline, LP, conducted an intensive pedestrian cultural resources survey within permitted areas of the 142.27-kilometer (88.4mile) long Lone Star Express II Pipeline Project - Loop 3, in Eastland, Comanche, Erath, and Bosque Counties, Texas. The lead agency for the project has been identified as the United States Army Corps of Engineers, Fort Worth District (Permit No. SWF-2019-00091). Thus, survey efforts concentrated on areas anticipated to be under the jurisdiction of the United States Army Corps of Engineers (permit areas). Within Loop 3, the total Area of Potential Effects within the permit areas measures approximately 209.9 hectares (518.6 acres). This area encapsulates approximately 52.8 kilometers (32.8 miles) of proposed project alignment. The procedures to be followed by the United States Army Corps of Engineers to fulfill the requirements set forth in the National Historic Preservation Act, other applicable historic preservation laws, and Presidential directives as they relate to the regulatory program of the United States Army Corps of Engineers (33 CFR Parts 320-334) are articulated in the Regulatory Program of the United States Army Corps of Engineers, Part 325 - Processing of Department of the Army Permits, Appendix C - Procedures for the Protection of Historic Properties.

All fieldwork and reporting activities were completed according to a scope of work submitted to the United States Army Corps of Engineers and the Texas Historical Commission and accepted standards set forth by the Texas Historical Commission and the Council of Texas Archeologists and in accordance with Section 106 of the National Historic Preservation Act.

A records and literature review of the project location prior to survey identified 13 previously recorded archaeological sites, four historic markers, five cemeteries, and five previously conducted surveys within a 0.8 -kilometer $(0.5$-mile) radius of Loop 3. Of those, the mapped locations for one recorded archaeological site and three previous surveys intersect the project corridor. An additional three archaeological sites are located within 91 meters (300 feet) of the project's Areas of Potential Effects. Fieldwork on Loop 3 was conducted in the Spring of 2019 with supplemental survey in August, October, and November of 2019 and required approximately 3,680-person hours to complete. Survey involved archaeological reconnaissance and shovel testing throughout anticipated permit areas within the project corridor. In total, approximately 901 shovel tests were excavated within permit areas, of which four were positive for cultural material.

No portions of previously recorded resources: 41ER48, 41ER49, 41ER50, or 41ER56, were reidentified; however, two new previously unrecorded resources, 41BQ358 and 41BQ359, and one isolate, BQ-07-ISO-01, were discovered. The newly recorded resources consist of sparse Prehistoric lithic scatters, consisting mainly of debitage and lacking temporally or culturally diagnostic artifacts. The lone diagnostic artifact, Isolate BQ-07-ISO-01, consists of an Ellis or Godley type projectile point dating to the Late to Transitional Archaic. The resource areas within the pipeline corridor showed clear disturbance from the adjacent pipeline right-of-way. Indications of soil deflation, erosion, and past land modifications such as agriculture or terracing were also observed. Further, Resource 41BQ358 and Isolate BQ-07-ISO-01 are located on very spatially limited topographic settings surrounded by slopes of 30 degrees or greater. The workspace at the location of 41BQ359 has been revised to avoid the site thus removing it from permitting. The workspace where it passes the site will be marked by orange fencing.

Shovel test results at nearly all permit areas identified subsoils, cemented soils, or bedrock. Alarm Creek in Erath County, Permit Area Number 65, was targeted for deep testing based on 
geomorphological data, and field results and discussions with the field archaeologist. Deep test results indicated a lack of deeply buried A horizon soils and showed no potential for deeply buried cultural material or paleosols. No cultural features or historic-age standing resources were encountered in the field. No artifacts were collected as a result of survey.

It is the opinion of Gray \& Pape Inc. that none of the recorded resources retain the potential to provide significant research value and are thus recommended not eligible for the National Register, under Evaluation Criterion D. In addition, the resources are recommended not eligible for State Antiquities Landmark status. Gray \& Pape, Inc. recommends no additional archaeological work for these resources or surveyed portions of the project. However, Gray \& Pape, Inc. recommends that an unanticipated discoveries plan be put into place in the event that such discoveries take place during construction. 


\section{TABLE OF CONTENTS}

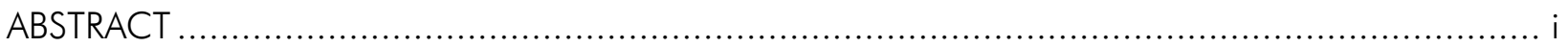

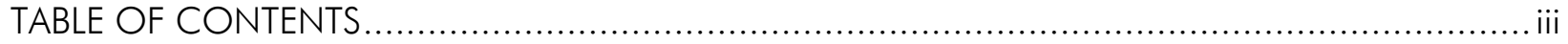

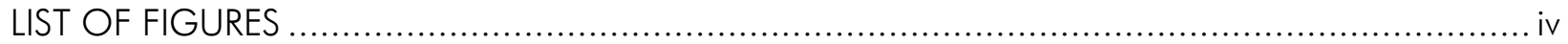

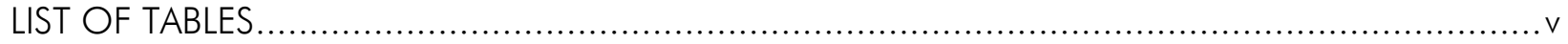

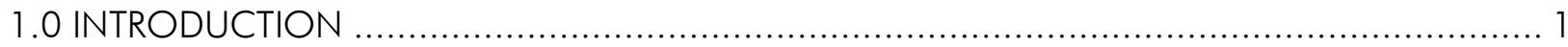

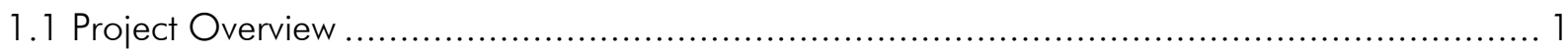

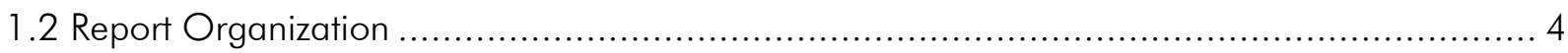

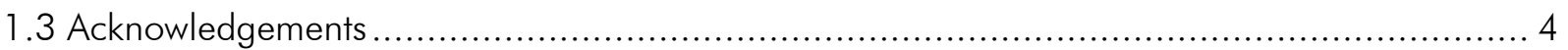

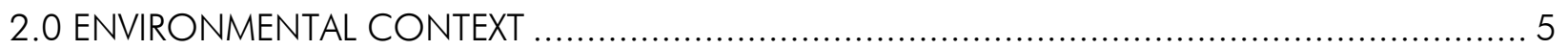

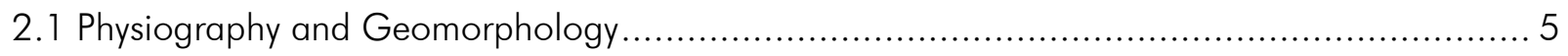

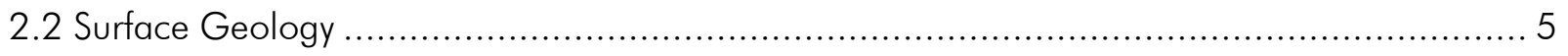

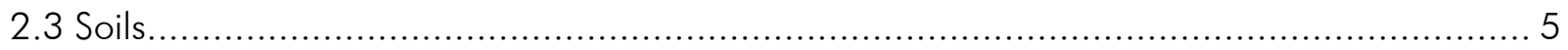

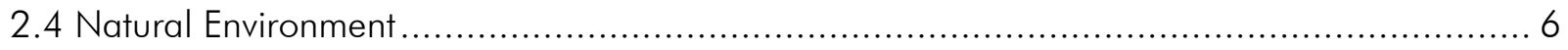

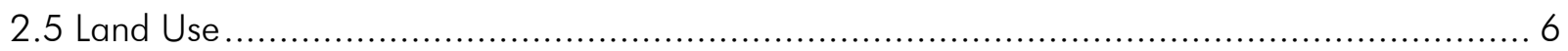

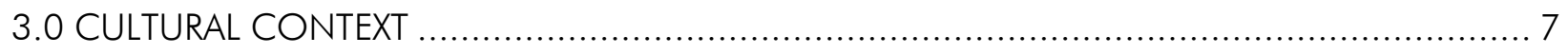

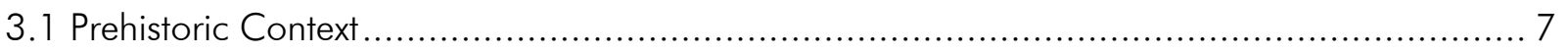

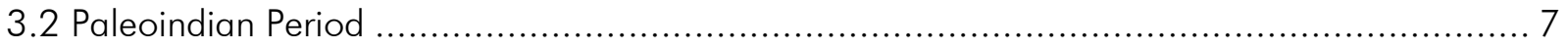

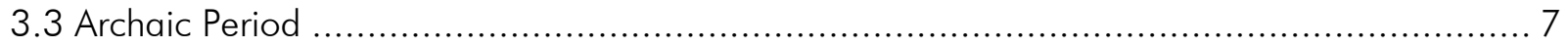

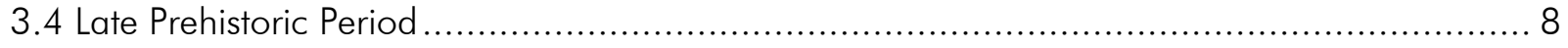

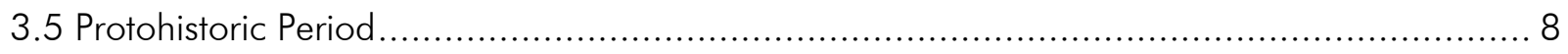

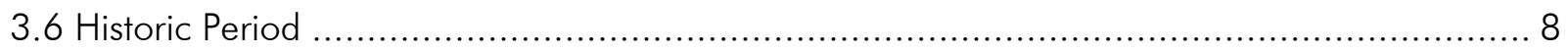

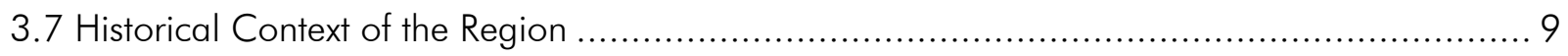

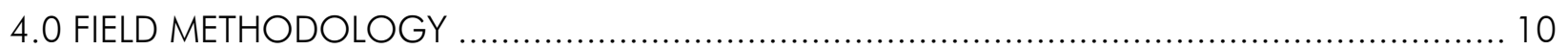

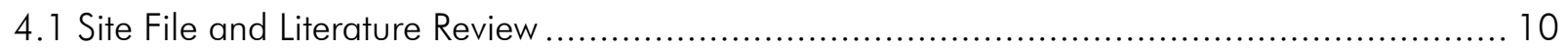

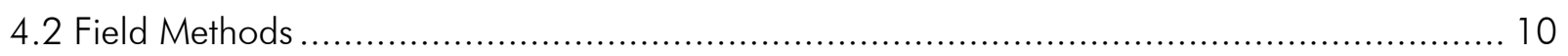

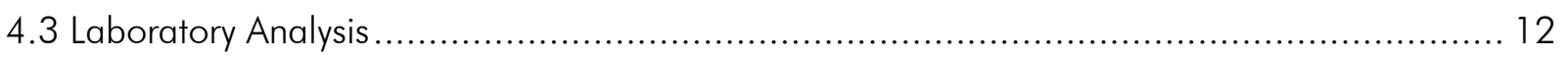

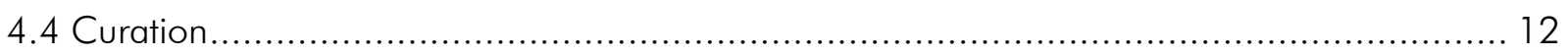

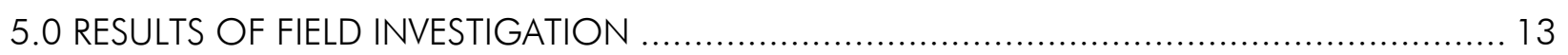

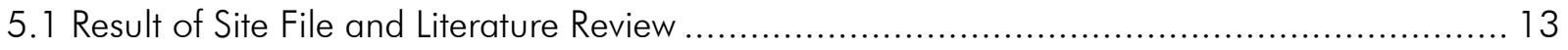

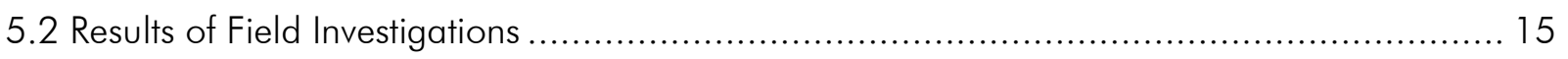

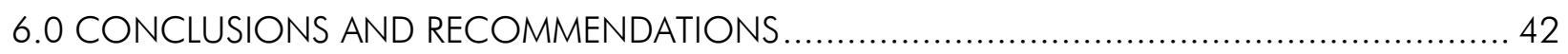


APPENDIX A: PERMIT AREAs WITHIN THE LOOP 3 ALIGNMENT.

APPENDIX B: FIELD RESULTS WITHIN PERMIT AREAS ALONG THE PROPOSED LOOP 3 PROJECT ALIGNMENT.

APPENDIX C: SHOVEL TEST LOG.

\section{LIST OF FIGURES}

Figure 1-1. Loop 3 Project segment in Eastland, Comanche, Erath, and Bosque Counties, Texas...... 2 Figure 5-1. Overview of typical field conditions observed within pastured areas of Loop 3. View is to

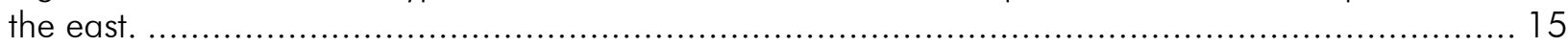
Figure 5-2. Overview of typical field conditions observed within wooded areas of Loop 3. View is to the south. 21

Figure 5-3. Overview of typical field conditions observed within disturbed areas of Loop 3 where subsoil was visible on the surface. View is to the northeast. .......................................... 21

Figure 5-4. Exposed bedrock as seen within the survey corridor. View is to the northwest.............. 21 Figure 5-5. Overview of the location of Resource 41BQ358 within the APE. View is to the northeast.

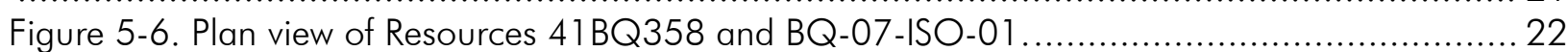

Figure 5-7. Representative materials identified within Resource 41BQ358.................................. 23

Figure 5-8. Overview of the location of Isolate BQ-01-ISO-01. View is to southwest ................... 25

Figure 5-9. Projectile point which comprises Isolate BQ-01-ISO-01 ................................... 25

Figure 5-10. Overview of the location of Resource 41BQ359. View is to the northeast................ 26

Figure 5-11. Representative lithics identified within Resource 41BQ359.............................. 26

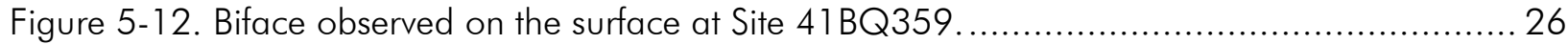

Figure 5-13. Plan view of Resource 41BQ359........................................................ 27

Figure 5-14. Mapped location of Resource 41 ER48 within the Loop 3 corridor. View is to the west. 30 Figure 5-15. Plan view of Resource 41 ER48. ........................................................... 31

Figure 5-16. Overview of the APE where it passes near the previously recorded location of Resource

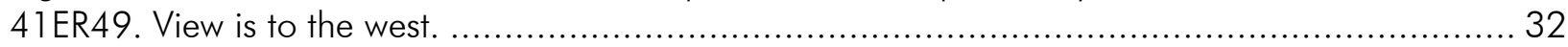

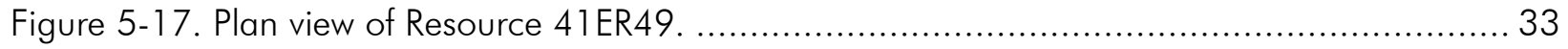

Figure 5-18. Overview of the APE where it passes near the previously recorded location of Resource

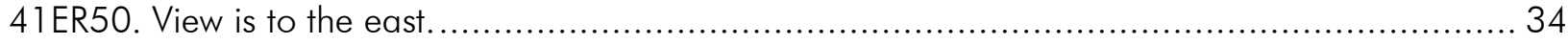

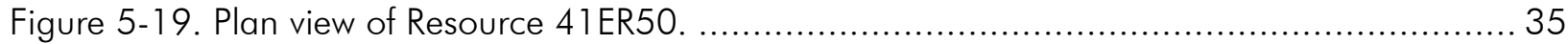
Figure 5-20. Overview of the APE where it passes near the previously recorded location of Resource

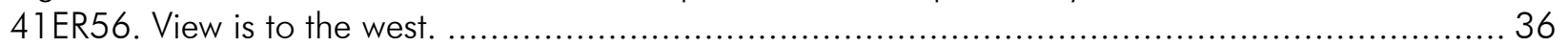

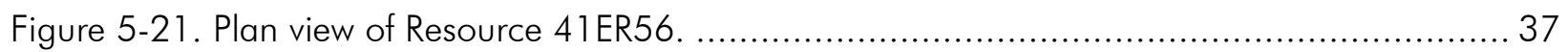

Figure 5-22. Overview of a harvested ag field south of Alarm Creek and CR 246. View is to the

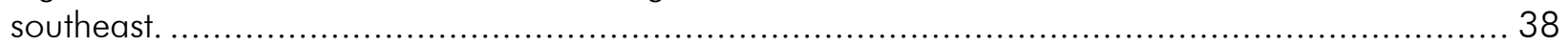
Figure 5-23. Overview of deep test locations to the west/north of Alarm Creek. View is to the

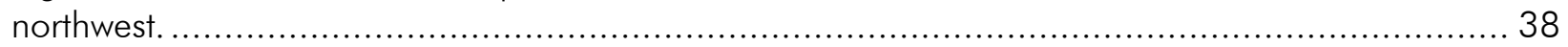

Figure 5-24. Bobcat equipped with an auger bit for deep testing. View is to the northwest............ 38 Figure 5-25. Representative soil profile as observed in Deep Test 1 at Alarm Creek.................... 39 Figure 5-26. Deep test locations within Permit Area 65 at Alarm Creek.................................. 40 


\section{LIST OF TABLES}

Table 1 - 1. USGS Quadrangles Intersecting Loop 3. .................................................. 3

Table 1-2. Natural Waterways Crossed by Loop 3 ..................................................... 3

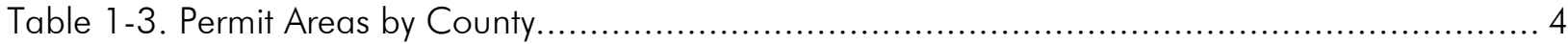

Table 2-1. Geologic Groups/Formations Intersected by Loop 3.................................... 5

Table 5-1. Previously Recorded Area and Linear Surveys within 0.8 Kilometers (0.5 Miles) of the Proposed Loop 3 Project Area. ............................................................................ 14

Table 5-2. Previously Recorded Archaeological Resources within 91 Meters (300 Feet) of the Loop 3

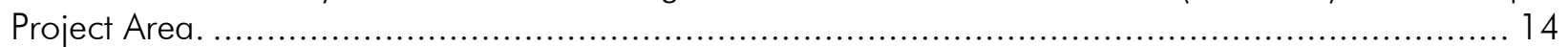

Table 5-3. Historical Markers Located within 0.8 Kilometers (0.5 Miles) of the Proposed Loop 3

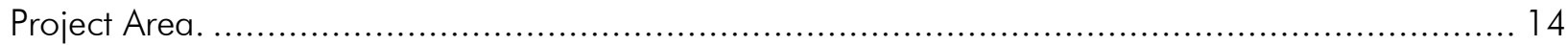

Table 5-4. Previously Recorded Cemeteries Located within 0.8 Kilometers (0.5 Miles) of the Proposed

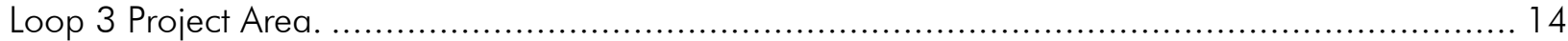

Table 5-5. Newly Recorded Cultural Resources Identified as a Result of Survey. ........................ 15

Table 5-6. Survey Results within Permit Areas of the Loop 3 Project Area............................... 16

Table 5-7. Newly Identified Resources within the Loop 3 Permit Areas. ..................................... 20

Table 5-8. Newly Identified Resources outside of Loop 3 Permit Areas.................................... 20

Table 5-9. Provenience of Subsurface Materials Identified within Resource 41BQ358.................. 23

Table 5-10. Artifact Assemblage Observed at 41BQ358.................................................... 23

Table 5-1 1. Artifact Assemblage Observed at 41BQ359................................................ 26

Table 5-12. Previously Recorded Resources Not Re-Identified within the APE............................ 29

Table 5-13. Deep Test Profiles from the Project Area at Alarm Creek. ................................. 41

Table 6-1. Summary of Resources Identified within the APE............................................. 42 


\subsection{INTRODUCTION}

EDGE Engineering and Science, LLC (EDGE), of Houston, Texas, contracted with Gray \& Pape, Inc. (Gray \& Pape), of Houston, Texas, to perform an intensive pedestrian cultural resources survey within portions of the Area of Potential Effects (APE) of the Lone Star Express II Pipeline Project - Loop 3, located in Eastland, Comanche, Erath, and Bosque Counties, Texas.

The entire project is located on private property. The lead agency for permitting purposes has been determined to be the United States Army Corps of Engineers, Fort Worth District (Corps or USACE). Thus, survey efforts were conducted within portions of the APE anticipated to be within Corps permit areas. The procedures to be followed by the USACE to fulfill the requirements set forth in the National Historic Preservation Act (NHPA), other applicable historic preservation laws, and Presidential directives as they relate to the regulatory program of the USACE (33 CFR Parts 320-334) are articulated in the Regulatory Program of the USACE, Part 325 Processing of Department of the Army Permits, Appendix C - Procedures for the Protection of Historic Properties. All fieldwork and reporting activities were completed with reference to state (the Antiquities Code of Texas) and federal (NHPA) guidelines.

The following report includes the results of the archaeological survey completed within jurisdictional permit areas along approximately 142.59 kilometers (88.60 miles) of centerline in Loop 3.

\subsection{Project Overview}

Lone Star NGL Pipeline, LP (Lone Star), proposes to construct a new pipeline loop in Eastland, Comanche, Bosque, and Erath Counties, Texas, referred to as the Lone Star Express II Pipeline Project - Loop 3 (LSXII -
Loop 3 or Project). The LSXII - Loop 3 Project will be approximately 142.59 kilometers (88.60) miles long and will be used to transport natural gas liquids (NGL). The purpose of the proposed Lone Star Express II Pipeline Project is to add approximately 400,000 barrels per day of NGL capacity to the existing Lone Star Express system which will help alleviate infrastructure constraints out of the Delaware and Permian basins in West Texas. The proposed Loop 3 portion of the Project will increase system capacity between the existing LSX3 Pump Station in Eastland County and the existing LSX4 Pump Station in Erath County, Texas. The proposed pipeline loop will generally be constructed within existing utility corridors and has been designed to parallel the existing Lone Star Express I Pipeline. New permanent facilities will be constructed alongside the existing Lone Star Express Pipeline facility locations where possible. Construction is currently scheduled to begin on September 1, 2019. The anticipated in-service date is January 2020.

Loop 3 intersects 15 USGS 7.5-minute topographic quadrangle maps (Figure 1-1, Table 1-1). Loop 3 begins in Eastland County approximately 13.7 kilometers (8.5 miles) southwest of Cisco at Interstate 20 and continues 108 kilometers (67 miles) southeast through Comanche and Erath Counties and into Bosque County before turning northeast for approximately 15.5 kilometers $(9.6$ miles) before turning west-southwest for 15 kilometers (9.3 miles) before terminating just south of Highway 174 approximately 6.9 kilometers (4 miles) west of Kopperl, Texas. Along that path the APE is largely collocated with an existing pipeline corridor and intersects several major and county roads, unimproved roads, agricultural fields and pastures. Loop 3 also crosses approximately 47 natural waterways (Table 1-2). 


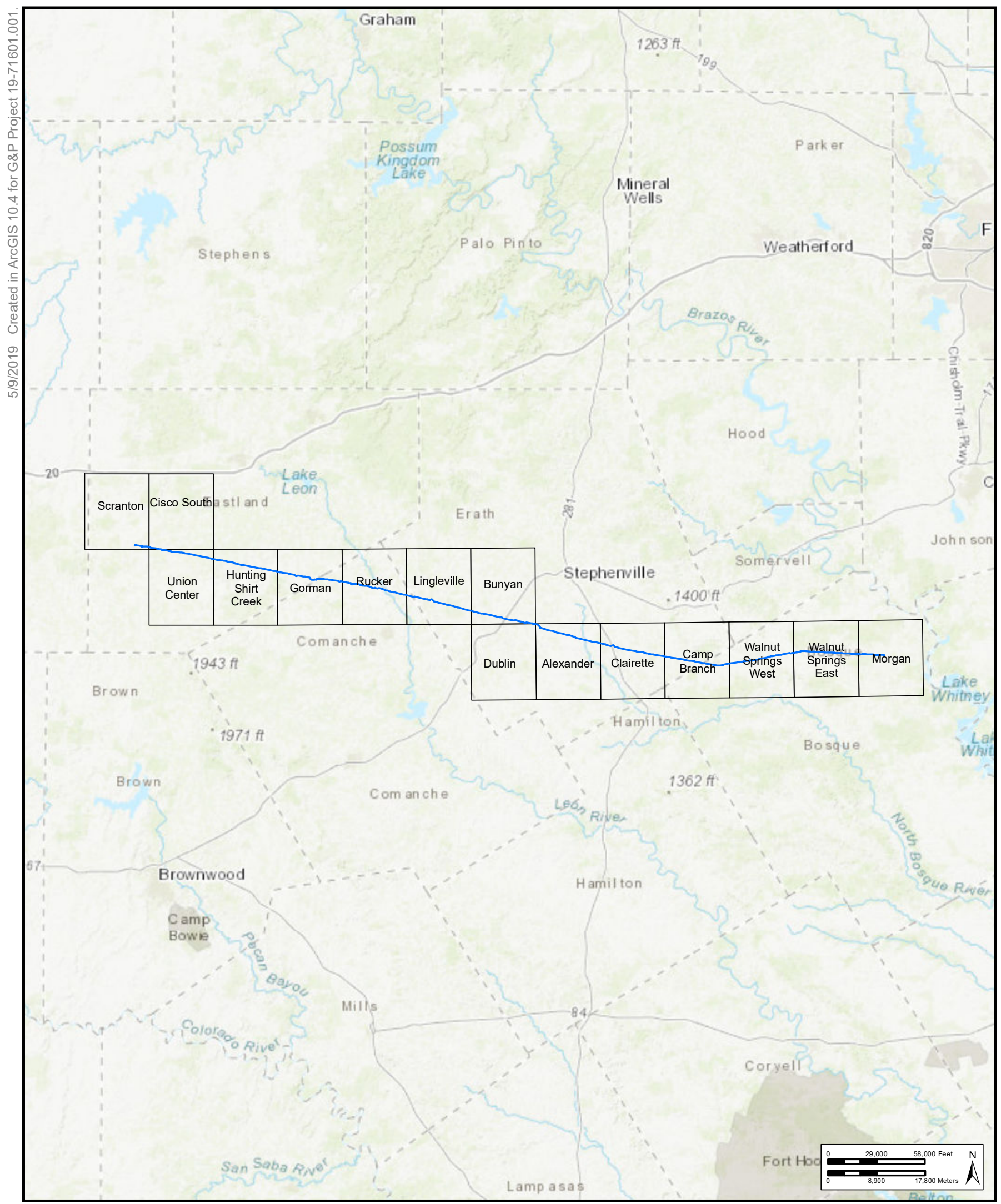

Figure 1-1

Project location in Eastland, Comanche, Erath, and Bosque Counties, Texas.

Project Location

$\square$ USGS Quadrangle Boundary

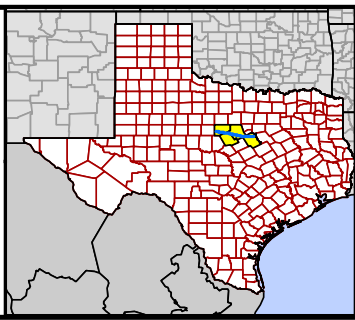


Table 1-1. USGS Quadrangles Intersecting Loop 3.

\begin{tabular}{|c|c|c|c|c|c|}
\hline USGS Quad ID & Name & State & Date Revised & $\begin{array}{c}\text { Date } \\
\text { Published }\end{array}$ & $\begin{array}{c}\text { Date Photo } \\
\text { Revised }\end{array}$ \\
\hline 32099-C1 & Scranton & Texas & - & 69 & - \\
\hline 32098-C8 & Cisco South & Texas & - & 70 & - \\
\hline 32098-B8 & Union Center & Texas & - & 72 & - \\
\hline $32098-B 7$ & Hunting Shirt Creek & Texas & - & 72 & - \\
\hline $32098-B 6$ & Gorman & Texas & - & 72 & - \\
\hline 32098-B5 & Rucker & Texas & - & 72 & - \\
\hline $32098-B 4$ & Lingleville & Texas & 76 & 79 & - \\
\hline $32098-B 3$ & Bunyan & Texas & - & 68 & 76 \\
\hline $32098-A 3$ & Dublin & Texas & - & 68 & 76 \\
\hline $32098-A 2$ & Alexander & Texas & 76 & 79 & - \\
\hline $32098-A 1$ & Clairette & Texas & 76 & 79 & - \\
\hline $32097-A 8$ & Camp Branch & Texas & - & 68 & 76 \\
\hline $32097-A 7$ & Walnut Springs West & Texas & - & 68 & 76 \\
\hline $32097-A 6$ & Walnut Springs East & Texas & 77 & 79 & - \\
\hline $32097-A 5$ & Morgan & Texas & - & 69 & 77 \\
\hline
\end{tabular}

Table 1-2. Natural Waterways Crossed by Loop 3.

\begin{tabular}{|l|}
\hline \multicolumn{1}{|c|}{ Waterway Name } \\
\hline Armstrong Creek \\
\hline Greer Creek \\
\hline Unnamed Tributary of Leon River \\
\hline North Bosque River \\
\hline Leon River \\
\hline Currycomb Branch \\
\hline Steele Creek \\
\hline Cat Branch \\
\hline Unnamed Tributary of Shirt Creek \\
\hline Sand Branch \\
\hline Duffau Creek \\
\hline Unnamed Tributary of Long Branch \\
\hline Round Hole Branch \\
\hline Cat Branch \\
\hline Unnamed Tributary of Cow Creek \\
\hline Unnamed Tributary of Sand Branch \\
\hline Cow Creek \\
\hline Mustang Creek \\
\hline Buck Branch \\
\hline Unnamed Tributary of Greer Creek \\
\hline Live Oak Creek \\
\hline Unnamed Tributary of Long Branch / Sabana River \\
\hline Unnamed Tributary of North Bosque River \\
\hline
\end{tabular}

\begin{tabular}{|l|}
\hline \multicolumn{1}{|c|}{ Waterway Name } \\
\hline Green Creek \\
\hline Unnamed Tributary of Green Creek \\
\hline Unnamed Tributary of Sabana River \\
\hline Rocky Creek \\
\hline Unnamed Tributary of Round Hole Branch \\
\hline Unnamed Tributary of Flat Creek \\
\hline Unnamed Tributary of Steele Creek \\
\hline Camp Branch \\
\hline Turkey Branch \\
\hline Farris Creek \\
\hline Walker Branch \\
\hline Cox Branch \\
\hline Unnamed Tributary of Sabana River \\
\hline Little Duffau Creek \\
\hline Unnamed Tributary of Shinoak Branch \\
\hline Unnamed Tributary of Sabana River \\
\hline Flat Creek \\
\hline Unnamed Tributary of Leon River \\
\hline East Bosque River \\
\hline Hunting Shirt Creek \\
\hline Alarm Creek \\
\hline Shinoak Branch \\
\hline Unnamed Tributary of Long Branch \\
\hline Unnamed Tributary of Round Hole Branch \\
\hline
\end{tabular}


The anticipated Corps Permit Area/APE for Loop 3 consists of approximately 124 locations subsuming 51.5 kilometers $(32$ miles) of centerline or approximately 203 hectares (502 acres) of Project survey corridor. The breakdown of area/length per county is provided in Table 1-3.

Table 1-3. Permit Areas by County.

\begin{tabular}{|c|c|c|c|}
\hline County & Permit Area Count & Acres & Miles \\
\hline Eastland & 21 & 101.20 & 7.00 \\
\hline Comanche & 16 & 58.80 & 3.50 \\
\hline Erath & 52 & 211.00 & 12.00 \\
\hline Bosque & 35 & 131.00 & 9.50 \\
\hline Total & 124 & 502.00 & 32.00 \\
\hline
\end{tabular}

\subsection{Report Organization}

This report is organized into seven numbered chapters and three lettered appendices. Chapter 1.0 provides an overview of the Project. Chapter 2.0 presents an overview of the environmental setting and geomorphology. Chapter 3.0 presents a discussion of the cultural context associated with the APE. Chapter 4.0 presents the research design and methods developed for this investigation. The results of this investigation are presented in Chapter 5.0. Chapter 6.0 presents the investigation summary and provides recommendations based on the results of field survey. A list of literary references cited in the body of the report is provided in Chapter 7.0.
Maps of the field survey results for Loop 3 are displayed in Appendices A and B. Appendix C contains a log of all excavated shovel tests.

\subsection{Acknowledgements}

Fieldwork on Loop 3 was conducted from March 26 to May 1, 2019 with supplemental survey activities conducted in August, October and November 2019. Fieldwork required approximately 3,680-person field hours to complete. The Project was managed by Senior Principal Investigator Tony Scott. Field activities were conducted by Field Leaders Chris Baltz, Matthew Kinsey, Monte Lawton, Kyle Mayer, Charlie Rose and Technicians Lindsay Gundler, William Leake, Marie Swartz, Kyle Potter, Jacob Seaton, Shelly White, Jonathan Cooper, Linsey Griffin, Petrina Kelly, Katrina Miller, Kaitlin Roberts, Steven Sykes, and Luis Gonzalez. The report was prepared by Tony Scott and Amanda Kleopfer. Graphics were produced by Tony Scott. Jessica Bludau edited and produced the report.

Gray \& Pape extends a special thank you to Lone Star Construction Manager Mike Churchman, Assistant Construction Manager Clyde McDonald, Pipeline Inspectors Bill Laird, David Bostic, Mark Salmon, Shane Holdridge, and Environmental Inspector Patrick Hill whose assistance and knowledge was instrumental in the timely and safe completion of the survey effort. 


\subsection{ENVIRONMENTAL CONTEXT}

\subsection{Physiography and Geomorphology}

Most of the Project is situated in the Interior Plains of the Central Lowland/Great Plains physiographic province. The Interior Plains are characterized by a nearly level to low rolling topography situated in the Edwards Plateau, Oakwoods and Prairies, and Blackland Prairies natural regions. Beginning in the rough hills of the Edwards Plateau, the surrounding topography quickly gives way to the rolling terrain of the Oakwood and Blackland Prairies, created by the effects of erosion from ancient streams, leaving a landscape that is also steeply sloped in areas of highly dissected riverine edges (Bureau of Economic Geology [BEG] 1996).

\subsection{Surface Geology}

Loop 3 crosses 14 geologic formations (Table 2-1). These formations largely consist of clay, mud, and shale surface horizons underlain by limestone, sandstone, or shale. Where overlying sands have been eroded away, the underlying deposits of silt, gravel, shale, and limestone are exposed. These can be up to 11 meters (35 feet) thick (Barnes 1967, 1977, 1983; Ferring 2007). Deposits crossed by the Project loop largely date from the Pennsylvanian to the Early Cretaceous.

\subsection{Soils}

Loop 3 intersects approximately 90 soils (Soil Survey Staff, Natural Resources Conservation Service, United States Department of Agriculture [SSS NRCS USDA] 2019) spread out across the four counties. Loop 3 is represented by Windthorst-Chaney-Duffau and Aledo-Sanger-Bolar soil associations (BEG 2008). Windthorst soils are characterized as fine sandy loam to loamy very fine sand surface layer overlying sandy clay. Duffau soils are very deep with a sandy clay loam to loamy fine sand surface layer that becomes yellowish red with depth.

Table 2-1. Geologic Groups/Formations Intersected by Loop 3.

\begin{tabular}{|c|c|c|c|c|}
\hline Label & Formation/Group & Age & Rock Type 1 & Rock Type 2 \\
\hline IPhc & $\begin{array}{l}\text { Home Creek Limestone and Colony Creek Shale, } \\
\text { undivided }\end{array}$ & $\begin{array}{l}\text { Pennsylvanian; Missouri } \\
\text { Series }\end{array}$ & shale & limestone \\
\hline IPpb & pre-Brazos River rocks, undivided & $\begin{array}{l}\text { Pennsylvanian; Des Moines } \\
\text { Series }\end{array}$ & mudstone & sandstone \\
\hline IPrp & Ranger Limestone and Placid Creek Shale, undivided & $\begin{array}{l}\text { Pennsylvanian; Missouri } \\
\text { Series }\end{array}$ & shale & limestone \\
\hline IPw & Winchell Limestone & $\begin{array}{l}\text { Pennsylvanian; Missouri } \\
\text { Series }\end{array}$ & limestone & shale \\
\hline IPwm & Wolf Mountain Shale & $\begin{array}{l}\text { Pennsylvanian; Missouri } \\
\text { Series }\end{array}$ & shale & sandstone \\
\hline $\mathrm{Ka}$ & Antlers Sand & Early Cretaceous & sand & clay or mud \\
\hline Kfu & undivided part Fredericksberg Group & Early Cretaceous & clay or mud & limestone \\
\hline Kgr & Glen Rose Limestone & Early Cretaceous & limestone & clay or mud \\
\hline $\mathrm{Kpa}$ & Paluxy Sand & Early Cretaceous & sand & sandstone \\
\hline Ktm & Twin Mountains Formation & Early Cretaceous & sandstone & claystone \\
\hline Kwa & Walnut Clay & Early Cretaceous & clay or mud & limestone \\
\hline Kwu & undivided part of Washita Group & $\begin{array}{l}\text { Early Cretaceous; } \\
\text { Comanchean Series }\end{array}$ & clay or mud & limestone \\
\hline $\mathrm{PIPm}$ & Magdalena Formation & Pennsylvanian to Permian? & limestone & shale \\
\hline Qal & alluvium & Holocene & sand & silt \\
\hline
\end{tabular}


These soils are well drained and are found on nearly level or gently sloping uplands. The Chaney series are characterized as deep soils that are moderately well drained with a sandy surface layer overlying mottled sandy clay found on nearly level to sloping plains. The Bolar Series consists of deep, calcareous, loamy soils overlying layers with high amounts of lime (BEG 2008).

\subsection{Natural Environment}

The western portion of the Project area in Loop 3 is largely dominated by agricultural crops. As the Project moves east, the agricultural areas become more interspersed and, in some places, entirely replaced with Silver BluestemTexas Wintergrass Grassland and OakMesquite-Juniper Parks/Woods (BEG 2000). Wildlife include the critically endangered lesser prairie chicken, as well as mammal species such as deer, fox, raccoon, skunk, opossum, badger, ringtail cat, bobcat, coyote, and peccary (Griffith et al. 2007). Other species inhabiting the area include waterfowl, rattlesnake, raptor, and jackrabbit (Lowther 1981).

\subsubsection{Climate}

The Project area in Loop 3 has a warmtemperate, sub-humid climate with hot summers. Annual rainfall averages 74.1 centimeters (29.17 inches), most of which falls during the warm season from April through October (Wagner et al. 1977; Stringer 1980). Summer temperatures can be intense, but relatively low humidity and frequent thundershowers help break the hot weather into short periods. Winters are highly variable, with cold fronts, and occasional light snows, which melt rapidly (Wagner et al. 1977; Stringer 1980).

\subsection{Land Use}

Land use in Loop 3 is largely farmland and/or pasture and scrub brush; however, it is more pasture than farmland. A small portion of Loop 3 crosses a residential area on the outskirts of Gorman. Much of the Project length is collocated and shows clear signs of disturbance from adjacent pipeline corridors and supporting infrastructure. 


\subsection{CULTURAL CONTEXT}

\subsection{Prehistoric Context}

Prehistoric sites in the Southern High Plains and Central Plains regions are commonly found on the surface and in mixed context (Meltzer 1987). Sites are typically located along the remnants of draws, playas, and larger salina basins that have been filled in by eolian processes (Johnson and Holliday 2004). The majority of known prehistoric Clovis, Folsom, and Late Paleoindian archaeological sites in Texas are found in portions of the High Plains region near New Mexico and western Oklahoma. The general area was near the southernmost reach of now extinct megafauna in the United States and included mammoth and a large form of bison, which were frequently hunted by prehistoric groups.

Sites with historic components in the region date as far back to the 1700s as was recorded in Blanco Canyon. Most historic sites in the area represent materials left behind by Hispanic sheepherders called pastores, European buffalo hunters, military outfits, and Anglo dumpsites (Perttula 2004).

Archaeological materials that have contributed to the development of a five-period cultural chronology, as developed by Kelley (1964) and Prikryl (1990), in the area based on excavations at a handful of intact sites. For the purpose of this report, an attempt is made to generalize these periods in the following paragraphs; however, it should be noted that cultural periods are not equally represented across the varying ecological and physiographic areas that the Project intersects.

\subsection{Paleoindian Period}

The Paleoindian period falls within the latter part of the Pleistocene and into the early Holocene. It is generally agreed to have begun as far back as 11,500 years before present (B.P.) and continued until 8,500 B.P. and is marked by ubiquitous hunting and on-site butchering of megafauna in small nomadic groups.

The Paleoindian period is further subdivided into three more specific periods marked by projectile point technologies (Frison 1991; Holliday 1997; Wheat 1972; Wormington 1957). These include the well-known Clovis, Folsom, and Late Paleoindian periods. The Clovis period is thought to have endured at least 500 years during the latter part of the Pleistocene and its lithic technology is the oldest known in North America. Clovis points are lanceolate-shaped with short flutes (Turner and Hester 1993). Clovis points are large, heavy, and well-made tools that were used for puncturing the thick flesh of large game. The Folsom period, from 10,800-10,300 B.P., is also defined by a large fluted lanceolateshaped point. Folsom points look similar to the Clovis point, but are thinner, more symmetrical, evenly chipped on the edges, and have a single classic flute all the way up the center of the point (Turner and Hester 1993). The Late Paleoindian period, from 10,0008,500 B.P, is characterized by excellent craftsmanship of long, thin, narrow, lanceolate points without flutes. Instead, these points have parallel flakes and are ground with thinned bases typically accomplished with a few vertical flakes (Turner and Hester 1993). Paleoindian sites of note located in the Southern High Plains and Central Plains regions include the Lone Wolf Creek (41MH23), Midland (41MD1), and McClean (41TA29) sites.

\subsection{Archaic Period}

Following a transition to a warmer climate, the Archaic period is accepted to have lasted between 8,500-1,250 B.P. The Archaic period is marked by an adaptation to less abundant water resources and to more dependence on vegetation as a food source than compared to people living in the Paleoindian period 
(Johnson and Holliday 2004). The Archaic period is further subdivided into two periods, known as the Early and Late Archaic periods, which the former is characterized by a lack of occupational sites in the area during a time called the Altithermal when the land was hot, dry, and dusty. The Late Archaic is defined by a sudden increase in the number of sites around 4,500 B.P., when a noticeably milder climate with less hostile conditions returned to the area (Antevs 1954; Hughes 1991). Archaic sites are commonly associated with fewer megafauna kill sites than earlier Paleoindian sites. Such sites are often associated with an array of stemmed and later barbed dart points, ground stones, and hearths lined with burned stone and caliche-cobbles (Hofman 1989).

\subsection{Late Prehistoric Period}

The Archaic period was followed by the development of ceramic technology and the bow and arrow. These two inventions made way for significant sociocultural changes including a shift toward sedentism and decreased mobility. These developments are the hallmarks of the Late Prehistoric period, which lasted from A.D. 200-1450.

Because of more specific diagnostic traits associated with the Late Prehistoric, it is further subdivided into the Woodland period (A.D. 200-1450), the Palo Duro Complex (A.D. 500-1100), and the Antelope Creek Phase (A.D. 1200-1450). The Lake Creek Site in the Texas Panhandle represents the Woodland period in the High Plains, which is characterized by cordmarked ceramics, cornernotched Scallorn arrow points, and a large assemblage of lithic flake tools (Hughes 1962). Palo Duro Complex Sites are defined by the use of pit houses and evidence of plant food procurement and processing. The first evidence of such was gathered during excavations by Willey and Hughes (1978) of the Deadman's Terrace Site, more commonly called Deadman's Shelter.
Finally, the Antelope Creek Phase, sometimes called the Antelope Creek Focus is the most distinctive and well-known of the Late Prehistoric periods in the Panhandle. Hughes (1991:31) documents the highest density of Antelope Creek Sites occurring along the Canadian breaks. Antelope Creek sites are best known by their pueblo-like structures with numerous rooms. These sites are also commonly identified by the presence of bone tools, made from butchered bison, scrapers, grinding slabs for plant processing, and sometimes obsidian (Hughes 1991).

\subsection{Protohistoric Period}

The Protohistoric period dates from A.D. 1450 to $A D$ 1600. It is defined by documented trade activities with neighboring Pueblos, increased ceramic production projectile points that seem to be confined to one of two subdivisions of the Protohistoric. The Tierra-Blanca Complex and the Garza Complex are contemporary. The Tierra-Blanca Sites are thought to have traded with the New Mexico Pueblos and are typically identified by the presence of larger villages (Hughes 1991). The Garza Complex is associated with the Garza point type which seems to only appear at Garza Complex sites. Other point types found at Garza Complex sites include the Washita, Harrell, Lott, and Fresno (Hughes 1991).

\subsection{Historic Period}

Several Native American tribes are known to have inhabited the area prior to Spanish contact in 1541; these include the Apache, Comanche, Kiowa, and Kiowa-Apache (Newcomb 1961). In the nineteenth century, the area was inhabited by the Kiowa and Comanche tribes, who preferred free range over Oklahoma's reservations (Whitlock 1970). By then, the Comanche had displaced the Apache. It is widely known that by the nineteenth century, aboriginal groups remaining in the High Plains had begun exploiting horses for use during hunting and raiding. During that time, the Comanche were 
assigned by the Army to reservation life in Oklahoma (Newcomb 1961).

\subsection{Historical Context of the Region}

The earliest written descriptions of the northcentral region of Texas come as a result of Spanish exploration of the areas to the north and west of the current Project. The cliff on the north facing of the Canadian River was seen by Francisco Vásquez de Coronado in 1541 on his way east from Cíbola, leading him to name the plateau the Llano Estacado, or Palisaded Plain. In addition to recording the initial explorations of the Llano Estacado, Coronado developed the region's orientation toward the Hispanic Southwest. Coronado's efforts were mimicked by Juan de Oñate during an early seventeenth century expedition along the Canadian River. In 1872, the Llano Estacado was described by General Randolph Marcy as a "great North American desert" with "not a tree, bush or water" (Whitlock 1970).

Early on, white settlement in the region was sparse, with hostilities between settlers and Comanches a constant risk. In the 1870s, conflict between American buffalo hunters and regional Native-American tribes reached its apex in the Red River War. Military defeat and the slaughter of the buffalo herds forced the Comanches, Kiowa, Cheyenne, and Arapaho off the plains to reservations (Haley 2010). After removal of the Comanche, Anglo settlement of what is now Erath County and the surrounding areas increased sharply, with cotton farming becoming the main economic draw (Young 2017). 


\subsection{FIELD METHODOLOGY}

This cultural resource investigation was designed to identify and assess new and previously recorded cultural resources that may be impacted by the proposed Project. Desktop assessment and modeling were performed prior to initiating field investigations to better understand cultural, environmental, and geological settings. Results of the desktop assessment were then used to develop the field methodology.

\subsection{Site File and Literature Review}

The background literature search included a review of previously conducted cultural resource surveys in the vicinity of the proposed Project area, and of any historic document pertaining to the history of the area. Site file research was performed to identify all previously recorded archaeological sites within a 0.8-kilometer (0.5-mile) study radius of the Project area and any recorded historic structures eligible for the National Register of Historic Places (NRHP) or State Antiquities Landmark (SAL) listing located adjacent to the Project area. Site file research was done by reviewing records maintained by the Texas Archeological Research Laboratory in Austin, Texas, and by consulting Texas Historical Commission (THC).

Historical topographic maps and aerial photographs when available were reviewed to identify any historic structures, residential, and other structures that might be located close to or within the Project area. Historical maps of Texas and Texas counties were also reviewed in order to better understand the history of the region and to identify any potential historic trails and important historic sites located or crossing the Project area.

\subsection{Field Methods}

\subsubsection{Intensive Pedestrian Survey}

The Project was subjected to pedestrian survey within permit areas. Permit areas were based on water features which were field delineated by biological field crews in conjunction with the cultural resource survey. The permit areas for each water feature were assessed on a caseby-case basis but in general comprised the first terrace to first terrace of large perennial creeks and rivers that intersect the APE. For smaller streams and water features without terraces, a minimum baseline buffer area placed to either side of the water feature was assessed. These buffer areas consist of 180 linear meters $(600$ linear feet) to either side of larger perennial and intermittent drainages and 100 linear meters (300 linear feet) to either side of some intermittent and ephemeral drainages, wetlands, and catch basins. Preliminary permit areas were further modified based on additional data such as geological units, soils, riparian areas, and previously identified resources. Based on the Project's typical corridor width of 39.6 meters (130 feet), two transects were investigated, with additional transects added as needed for wider temporary workspaces. Transects were spaced no more than 30 meters (100 feet) apart. Because most of the Project APE is collocated with an existing pipeline corridor which at times subsumes half or more of the total corridor width, one survey transect was often within an existing pipeline easement. Existing easements were routinely maintained and often displayed greater than 30 percent surface visibility. Survey transects overlapping existing easements, excessive slope, or standing water were at a minimum subjected to pedestrian surface inspection/walkover, and also judgmentally shovel tested where warranted to confirm/refute suspected subsurface disturbance. Digital photography aided 
documentation of the existing conditions of the Project area and fieldwork methods, with photograph locations recorded on field maps and logged with a Global Positioning System (GPS) unit.

Shovel testing within permit areas was attempted along each transect at a number which met or exceeded Texas State Minimum Archaeological Survey Standards regardless of surface visibility. Shovel tests were generally spaced at intervals between 30 and 60 meters (100 and 200 feet). In areas of clear previous disturbance or areas of lower probability for cultural resources, shovel tests were not typically conducted at a distance greater than 100 meters (328 feet). Shovel tests were attempted to depths of 1 meter (3.3 feet) or until culturally sterile subsoil was reached, except where bedrock was present at shallow depths, or where potential existing pipelines were present.

All shovel tests measured approximately 30 centimeters by 30 centimeters ( 1 foot by 1 foot). When possible, all soil was screened through 0.64 -centimeter (0.25-inch) wire mesh. Vertical control of each shovel test was maintained by excavating in arbitrary 10centimeter (4-inch) levels with reference to the parent soil stratum. The profile of each shovel test was inspected for color and texture change potentially associated with the presence of cultural features. Descriptions of soil texture and color followed standard terminology and soil color charts (Munsell 2005). Additional information such as mottling, evidence of disturbance, and moisture level was also recorded. All shovel test data were recorded in one of two formats for analysis: GIS or standardized forms. All shovel tests were backfilled after excavation and documentation. The excavated shovel tests were placed on field maps and points were taken with a GPS unit.

At each permit area location, a summary of the results of activities along with recommendations was provided to the
Principal Investigator on a daily basis. These summaries were then submitted to the client. At regular intervals while survey was in progress shovel test forms were submitted to the Principal Investigator for review. Any need for additional work such as deep testing was based on the field results in coordination with the field archaeologist and arranged with the client.

\subsubsection{Deep Testing}

As documented in Chapter 5.2 below, shovel test results in nearly all permit areas indicated deflated soils with subsoil or bedrock near the surface. This is likely due to previous erosion and disturbance as a result of previous pipeline installations, the existing ROW of which subsumes the majority of the current APE. However, the location of Permit Number 65 at Alarm Creek in Erath County was identified as a candidate for deep testing. This determination was based on geomorphological data, and field results and discussions with the field archaeologists. The location is mapped for Holocene-age alluvial deposits which have the potential for a deep $A$ horizon. Shovel test results at the location could not confirm that subsoils were reached and as a result, deep testing for the location was advised by the field archaeologist. The methodology was formulated in conjunction with agency coordination. Agency consultation concurred with the use of machine auguring at the location. Auger tests were placed at 50meter (164-foot) intervals, conducted along a single transect placed outside of the existing pipeline right-of-way (ROW) for safety concerns. Mechanical auguring was conducted with reference to the most recent draft of the Council of Texas Archeologists (CTA) guidelines. Soil matrix removed during auguring was placed on plastic tarp to keep it separated from the surrounding vegetation. The removed material was monitored for texture and color changes and screened using $1 / 4$-inch mesh. Descriptions of soil texture and color followed standard terminology and the Munsell (2005) soil color charts. The locations 
of all deep tests were recorded with a submeter accurate GPS data collector and recorded on field maps.

\subsubsection{Site Definition}

Surface visibility along the entire Project length was generally 70 percent or greater. Thus, all previously recorded sites that intersect the APE within permit areas were subjected to surface inspection supplemented by a sample of shovel tests placed at regular intervals within the previously established site boundary to check for deposition and density. A minimum of six radial shovel tests were typically attempted conducted in cardinal directions around the site boundary within the limits of the APE. Delineation tests were typically conducted in 10-meter (33-foot) intervals but increased or decreased at the field archaeologist's discretion based on contributing field factors such as surface expression, previously established site size, previous disturbance, landforms, amount of surface visibility, and perceived areas of surface density. Delineation tests were generally pursued until reaching two consecutive negative tests beyond the established site boundary.

Newly identified sites were delineated in the same manner. Positive shovel tests, artifacts visible on the surface, and site boundaries were recorded on Project maps and via submeter accurate GPS. Newly identified sites and revisited previously recorded sites were also documented on standardized archaeological site forms.

For each cultural resource identified, including structures or other resources within or immediately adjacent to the APE, photographs were taken of the general vicinity and of any visible features if present. A sketch map was prepared showing site limits, feature locations, permanent landmarks, topographic and vegetation variations, sources of disturbances, and total number of tests performed within and near the site. Artifacts recovered from shovel tests were not to be collected. All discovered artifacts were photographed in the field and placed in the backfilled shovel test or left on the surface. Locations of all positive tests were recorded with the GPS.

Each identified resource was given a temporary field site number. Site forms were submitted for each cultural site identified. Revisit site forms were completed for previously recorded sites re-identified in the field. State-issued trinomial site numbers were requested for cultural sites but not for identified isolates.

If any architectural resources had been identified, these would have been recorded on corresponding field forms. Details of form, construction, material, style, condition, and alteration would be recorded both on the forms and photographically for each structure. All documentation would be reviewed by a qualified Architectural Historian who would decide if additional information or a personal field inspection was necessary at the survey level.

\subsection{Laboratory Analysis}

\subsubsection{Artifact Analysis}

Artifacts encountered in the field were not collected; thus, no lab analysis was conducted. Artifacts were instead described and classified in the field as best as possible and representative samples were photographed. Data recorded in the field for uncollected artifacts included general attributes such as form (if identifiable), material, functional classification (if identifiable), and counts.

\subsection{Curation}

No diagnostic or non-diagnostic artifacts were collected in the course of the current survey. Gray \& Pape will maintain Project records in their curation facility in Houston. 


\subsection{RESULTS OF FIELD INVESTIGATION}

\subsection{Result of Site File and Literature Review}

A search of the Texas Archeological Sites Atlas, maintained by the THC, determined that no National Register properties intersect the Project alignment within Loop 3. The same research identified that 13 previously recorded archaeological sites, five previously conducted archaeological surveys, four historical markers, and five cemeteries had been recorded within the 0.8 -kilometer $(0.5$-mile) study radius of the Project area.

\subsubsection{Previously Recorded Surveys}

According to a search of the Texas Archeological Sites Atlas, at least five previous surveys have been conducted within a 0.8 kilometer (0.5-mile) study radius of Loop 3 (Table 5-1, Appendix A). Three of those surveys intersect the Project alignment; however, these consist of narrow survey corridors and none significantly overlap the current Project. The most recent of these surveys were conducted by Horizon Environmental Services, Inc. (Horizon). Projects included the Lonestar Transmission Pipeline. A review of reports associated with these and other surveys in the vicinity indicated a mix between 100 percent survey coverage and survey of USACE jurisdictional water crossings. Survey findings suggests that while archaeological sites are not uncommon in the general vicinity, they do not typically contain the information that would result in a recommendation for eligibility. Some of these resources are discussed further in-depth below.

\subsubsection{Previously Recorded Archaeological Sites}

Per a search of the Texas Archeological Sites Atlas (2019), 13 previously recorded archaeological resources occur within the 0.8kilometer (0.5-mile) study radius of the Project area. Of those, four are located within 91 meters (300 feet) of the APE, with only one resource, 41ER48, mapped as intersecting the APE (Table 5-2). Site 41 ER48 is a historic-era farmstead originally recorded in 2011 for the Lone Star Competitive Renewable Energy Zone (CREZ) Transmission Line project by Horizon (Cochran et al. 2012). The site is located in the eastern portion of Erath County approximately 1.9 kilometers (1.2 miles) northwest of the intersection of Farm-to-Market (FM) 1824 and County Road (CR) 229. Cultural features observed at the site include the remnants of several historic structures: a house, a barn, two side-by-side corn-crib structures, a possible collapsed cellar, a limestone wall structure, a collapsed windmill, and a fenced-in corral area with a corrugated metal door. Ten canine graves were also discovered near the corn-crib structures. Artifacts present at Site 41ER48 include: whiteware fragments, clear, blue, brown and milk glass fragments, clear, brown and blue glass bottles, clear glass jars, metal fragments, metal stoves, wooden planks, red cherry bricks and brick fragments, window/door hinges, and pieces of metal piping and farm equipment (Texas Archeological Sites Atlas 2019).

\subsubsection{Historical Markers}

Four historical markers are recorded within 0.8 kilometers (0.5 miles) of the Project (Table 5-3; Figures A8, A24, and A25). The closest of these, the Duffau Cemetery (Marker No. 1293), is located 173 meters (569 feet) from the survey corridor at its nearest.

\subsubsection{Cemeteries}

Five cemeteries are located within the 0.8kilometers (0.5-miles) radius of the Loop 3 Project area (Table 5-4; Figures A11, A18, and A25). The closest of these, Jewel Cemetery (No. EA-C008), is located 275 meters (902 feet) from the survey corridor at its nearest point. 
Table 5-1. Previously Recorded Area and Linear Surveys within 0.8 Kilometers (0.5 Miles) of the Proposed Loop 3 Project Area.

\begin{tabular}{|c|c|c|c|c|c|c|}
\hline $\begin{array}{l}\text { Project } \\
\text { Type }\end{array}$ & Date & $\begin{array}{l}\text { TAC Permit } \\
\text { No. }\end{array}$ & Sponsor/Agency & $\begin{array}{l}\text { Investigating } \\
\text { Firm }\end{array}$ & Report Author & $\begin{array}{c}\text { THC Review } \\
\text { Date }\end{array}$ \\
\hline $\begin{array}{l}\text { *Area } \\
\text { Survey }\end{array}$ & $8 / 1 / 2012$ & - & $\begin{array}{c}\text { USACE, US Fish and } \\
\text { Wildlife }\end{array}$ & Horizon & $\begin{array}{c}\text { Cochran, } \\
\text { Jennifer, et al. }\end{array}$ & $1 / 4 / 2013$ \\
\hline $\begin{array}{l}\text { *Area } \\
\text { Survey }\end{array}$ & $2 / 1 / 1996$ & - & $\begin{array}{c}\text { Federal Highway } \\
\text { Administration, TXDOT }\end{array}$ & - & - & - \\
\hline $\begin{array}{l}\text { Linear } \\
\text { Survey }\end{array}$ & $5 / 1987$ & - & TXDOT & - & - & - \\
\hline $\begin{array}{l}* \text { Linear } \\
\text { Survey }\end{array}$ & 8/1993 & - & REA & - & - & - \\
\hline $\begin{array}{l}\text { Linear } \\
\text { Survey }\end{array}$ & $1 / 2001$ & - & USDA-RD & - & - & - \\
\hline
\end{tabular}

${ }^{*}$ Indicates an intersection with the current Project.

Table 5-2. Previously Recorded Archaeological Resources within 91 Meters (300 Feet) of the Loop 3 Project Area.

\begin{tabular}{|c|c|c|c|c|c|c|}
\hline Trinomial & Site Type & $\begin{array}{c}\text { Cultural } \\
\text { Affiliation }\end{array}$ & Materials observed & $\begin{array}{c}\text { Record } \\
\text { Date }\end{array}$ & NRHP Status & $\begin{array}{c}\text { NRHP Review } \\
\text { Date }\end{array}$ \\
\hline *41ER48 & Farmstead & Historic & $\begin{array}{c}\text { Structures, whiteware, clear, blue, } \\
\text { brown, and milk glass, metal, } \\
\text { brick, wood, farming equipment. }\end{array}$ & 2011 & Ineligible & 2012 \\
\hline 41 ER49 & $\begin{array}{c}\text { Artifact } \\
\text { Scatter }\end{array}$ & Historic & $\begin{array}{c}\text { Whiteware, brown glass bottle } \\
\text { base, spun yarn, blue-green glass. }\end{array}$ & 2011 & $\begin{array}{c}\text { Ineligible } \\
\text { within ROW }\end{array}$ & 2012 \\
\hline 41 ER50 & $\begin{array}{c}\text { Artifact } \\
\text { scatter }\end{array}$ & $\begin{array}{c}\text { Prehistoric/ } \\
\text { Historic }\end{array}$ & $\begin{array}{c}\text { Whorked chert flake, metal, } \\
\text { whiteware, brown glass bottle } \\
\text { base. }\end{array}$ & 2011 & $\begin{array}{c}\text { Ineligible } \\
\text { within ROW }\end{array}$ & 2012 \\
\hline 41 ER56 & $\begin{array}{c}\text { Artifact } \\
\text { Scatter }\end{array}$ & $\begin{array}{c}\text { Prehistoric } \\
\text { and Historic }\end{array}$ & $\begin{array}{r}\text { Chert flake, chert tool fragment, } \\
\text { whiteware }\end{array}$ & 2012 & $\begin{array}{c}\text { Ineligible } \\
\text { within ROW }\end{array}$ & 2012 \\
\hline
\end{tabular}

*Indicates an intersection with the APE.

Table 5-3. Historical Markers Located within 0.8 Kilometers (0.5 Miles) of the Proposed Loop 3 Project Area.

\begin{tabular}{|c|l|c|l|}
\hline Marker Number & \multicolumn{1}{|c|}{ Name } & Marker Year & \multicolumn{1}{c|}{ Description } \\
\hline 1292 & Duffau Baptist Church & 1979 & $\begin{array}{l}\text { Dedicated to the early establishment of the Baptist church in the } \\
\text { local community. }\end{array}$ \\
\hline 1293 & Duffau Cemetery & 1997 & $\begin{array}{l}\text { Dedicated to the early settlement of the area, the cemetery } \\
\text { contains more than } 950 \text { marked graves, the earliest dating to } \\
1865 .\end{array}$ \\
\hline 4810 & Old Shinoak Springs & 1966 & $\begin{array}{l}\text { Dedicated to the natural water resources in the area and their use } \\
\text { and impact on the communities that arose around them. }\end{array}$ \\
\hline 4253 & Hurley, Rev. Henry & 1983 & $\begin{array}{l}\text { Dedicated to the early establishment of the Baptist church and } \\
\text { religious leaders in the local community. }\end{array}$ \\
\hline
\end{tabular}

Table 5-4. Previously Recorded Cemeteries Located within 0.8 Kilometers (0.5 Miles) of the Proposed Loop 3 Project Area.

\begin{tabular}{|c|l|l|}
\hline Cemetery Number & \multicolumn{1}{|c|}{ Name } & \multicolumn{1}{c|}{ County } \\
\hline CJ-C043 & Unknown (Oliver Springs Ch) & Comanche \\
\hline EA-C008 & Jewel & Eastland \\
\hline EA-C023 & Romney & Eastland \\
\hline ER-C006 & Duffau & Erath \\
\hline ER-C035 & Lower Green's Creek & Erath \\
\hline
\end{tabular}




\subsection{Results of Field \\ Investigations}

Fieldwork included archaeological reconnaissance throughout USACE permit areas within the APE. During the survey of Loop 3, permit areas surrounding 235 water features were investigated, consisting of streams, rivers, wetlands, and ponds/catch basins. These areas were encapsulated by 124 permit areas. In total, 901 shovel tests were excavated within the permit areas. Of those, four were positive for cultural materials resulting in the discovery of two new resources and one isolate find (Tables $5-5$ to 5-8). Resource and artifact descriptions are provided in more detail in Section 5.2.3 below.

Table 5-5. Newly Recorded Cultural Resources Identified as a Result of Survey.

\begin{tabular}{|c|c|l|}
\hline Field ID & Trinomial & \multicolumn{1}{|c|}{ Description } \\
\hline BQ-07-01 & $41 B Q 358$ & Prehistoric lithic scatter \\
\hline BQ-38-01 & 41BQ359 & Prehistoric lithic scatter \\
\hline BQ-07-ISO-01 & - & Projectile Point \\
\hline
\end{tabular}

\subsubsection{Loop 3 General Characteristics}

The loop's setting largely consisted of grassland pastures (Figure 5-1) and woods (Figure 5-2). Vegetation observed within the APE includes mesquite trees, sycamore trees, greenbrier, short annual grasses, Post Oak and Black Jack Oak trees. Surface visibility generally ranged from 20 to 100 percent. At least half of the survey corridor has been previously impacted by the adjacent pipeline installations, maintenance, or subsequent erosion (Figure 5-3). In many places, subsoil or bedrock is exposed at the surface (Figure 54). Within Loop 3, 901 shovel tests were excavated (see maps in Appendix B and Shovel
Test Log in Appendix C). While the project intersects areas mapped for at least 90 soils series, permit areas most often intersected areas mapped for Windthorst, Purves, Cheney, Pedernales, and Maloterre soils. These soils

The typical shovel test profile for most of the loop consisted of brown or dark yellowish brown (10YR $4 / 3$ or 4/4) silt loam or silty clay loam followed by a subsurface layer of deflated silt loam. However, some portions consisted of light yellowish brown (10YR 6/4) sand or loamy sand followed by brownish yellow (10YR 6/6) hydric sand or clay. The depth of the surface and subsurface layers was typically shallow (5 to 50 centimeters 2 to 20 inches]), indicating past impact by erosion or land modification. In most tests, these layers were underlain by a layer of cemented caliche or limestone bedrock. Because of this, very few tests approached 100 centimeters (33 inches). Approximately 148 shovel tests showed evidence of disturbance displayed as mottled soils containing larger quantities of calcium carbonate or gravels throughout. These tests typically were located within or very near the existing pipeline corridor limits.

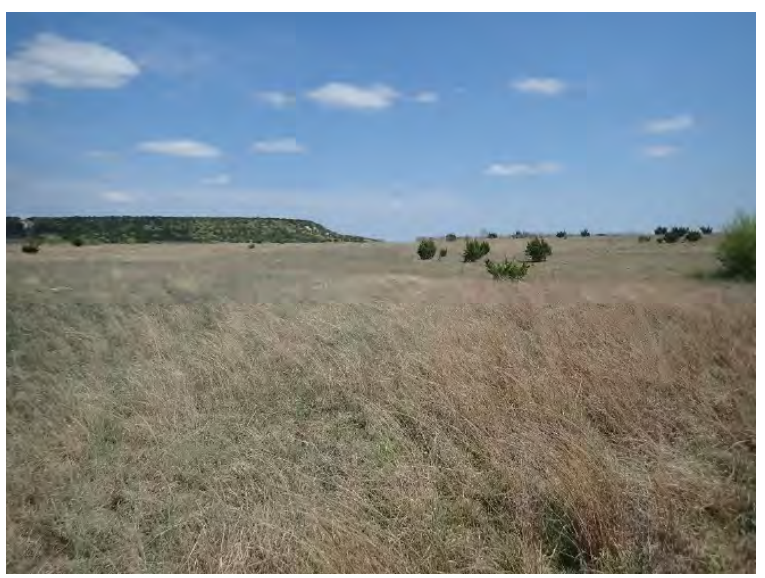

Figure 5-1. Overview of typical field conditions observed within pastured areas of Loop 3. View is to the east. 
Table 5-6. Survey Results within Permit Areas of the Loop 3 Project Area.

\begin{tabular}{|c|c|c|c|c|c|c|c|c|c|}
\hline $\begin{array}{c}\text { Permit Area } \\
\text { No. }\end{array}$ & Parcels & Miles & Acres & UTME & UTM N & $\begin{array}{c}\text { Shovel Test } \\
\text { Count }\end{array}$ & $\begin{array}{l}\text { Resources } \\
\text { Identified }\end{array}$ & $\begin{array}{l}\text { Appendix A } \\
\text { Figure }\end{array}$ & $\begin{array}{l}\text { Appendix B } \\
\text { Figure }\end{array}$ \\
\hline 1 & LSX-EA-023.000, LSX-EA-024.000 & 0.17 & 3.17 & 499078.19 & 3568655.90 & 1 & & $\mathrm{Al}$ & $\mathrm{B} 1$ \\
\hline 2 & LSX-EA-029.000 & 0.12 & 1.97 & 503559.27 & 3567882.67 & 5 & & A2 & B2 \\
\hline 3 & LSX-EA-034.000 - LSX-EA-036.000 & 0.23 & 3.73 & 504230.10 & 3567668.63 & 9 & & A2 & B3 \\
\hline 4 & LSX-EA-040.000, LSX-EA-041.000, LSX-EA-041.100 & 0.27 & 4.36 & 505738.90 & 3567541.18 & 13 & & A3 & B4 \\
\hline 5 & LSX-EA-054.000 & 0.36 & 6.08 & 511855.87 & 3566329.60 & 13 & & A4 & B5 \\
\hline 6 & LSX-EA-056.000, LSX-EA-057.000 & 0.25 & 3.98 & 513156.04 & 3566168.81 & 4 & & A4 & B6 \\
\hline 7 & LSX-EA-057.000, LSX-EA-058.000 & 0.13 & 1.41 & 513525.04 & 3566101.53 & 2 & & A5 & B7 \\
\hline 8 & LSX-EA-058.000 & 0.23 & 4.06 & 514393.36 & 3565940.52 & 3 & & A5 & B8 \\
\hline 9 & LSX-EA-058.000, LSX-EA-062.000 / LSX-EA-063.000 & 0.15 & 2.96 & 515094.30 & 3565791.06 & 2 & & A5 & B9 \\
\hline 10 & LSX-EA-068.000, LSX-EA-069.000, LSX-EA-070.000 & 1.22 & 19.86 & 518316.96 & 3565039.19 & 51 & & A6 & $\mathrm{B} 10$ \\
\hline 11 & LSX-EA-074.000 & 0.51 & 8.42 & 521966.01 & 3564369.96 & 13 & & A7 & $\mathrm{B} 11$ \\
\hline 12 & LSX-EA-076.000 - LSX-EA-077.000 & 0.26 & 4.66 & 522653.42 & 3564238.54 & 10 & & A7 & $\mathrm{B} 12$ \\
\hline 13 & LSX-EA-077.000, LSX-EA-078.000 & 0.33 & 5.12 & 523331.98 & 3564116.72 & 15 & & A7 & $\mathrm{B} 13$ \\
\hline 14 & LSX-EA-080.200, LSX-EA-080.300, LSX-EA-080.400, LSX-EA-081.000 & 0.52 & 3.57 & 525347.78 & 3563735.18 & 6 & & A8 & B14 \\
\hline 15 & LSX-EA-081.100, LSX-EA-081.200, LSX-EA-082.000, LSX-EA-083.000 & 0.52 & 4.68 & 525799.17 & 3563650.83 & 10 & & A8 & B15 \\
\hline 16 & LSX-EA-084.000, LSX-EA-085.000 & 0.27 & 4.80 & 526603.19 & 3563458.92 & 16 & & A8 & B16 \\
\hline 17 & LSX-EA-086.000, LSX-EA-088.000 & 0.26 & 4.46 & 527279.43 & 3563335.31 & 8 & & A8 & $\mathrm{B} 17$ \\
\hline 18 & LSX-EA-088.000, LSX-EA-089.000 & 0.11 & 2.26 & 527977.74 & 3563240.11 & 3 & & A8 & $\mathrm{B} 18$ \\
\hline 19 & LSX-EA-090.000, LSX-EA-091.000 & 0.50 & 4.10 & 529283.40 & 3562984.55 & 2 & & A8 & B19 \\
\hline 20 & LSX-EA-091.000 & 0.50 & 5.52 & 529510.34 & 3562701.16 & 3 & & A9 & B20 \\
\hline 21 & LSX-EA-092.000, LSX-EA-093.000 & 0.12 & 1.98 & 529995.46 & 3562555.86 & 4 & & A9 & B21 \\
\hline 22 & LSX-CO-002.000, LSX-CO-003.000 & 0.12 & 2.06 & 531490.88 & 3562728.14 & 4 & & A9 & B22 \\
\hline 23 & LSX-CO-006.000, LSX-CO-007.000 & 0.14 & 2.30 & 533276.51 & 3562554.69 & 4 & & A9 & B23 \\
\hline 24 & LSX-CO-008.000 & 0.15 & 2.85 & 534048.32 & 3562435.61 & 3 & & A10 & B24 \\
\hline 25 & LSX-CO-009.000 & 0.21 & 3.33 & 534820.79 & 3562273.71 & 6 & & A10 & B25 \\
\hline 26 & LSX-CO-009.000, LSX-CO-010.000 & 0.12 & 1.98 & 535339.35 & 3562244.44 & 2 & & $\mathrm{~A} 10$ & B26 \\
\hline 27 & LSX-CO-010.000, LSX-CO-011.000 & 0.23 & 3.62 & 536158.24 & 3562122.74 & 2 & & $\mathrm{~A} 10$ & B27 \\
\hline 28 & LSX-CO-016.000 & 0.18 & 2.76 & 538091.22 & 3561806.18 & 5 & & A11 & $\mathrm{B} 28$ \\
\hline
\end{tabular}




\begin{tabular}{|c|c|c|c|c|c|c|c|c|c|}
\hline $\begin{array}{c}\text { Permit Area } \\
\text { No. }\end{array}$ & Parcels & Miles & Acres & UTM E & UTM N & $\begin{array}{c}\text { Shovel Test } \\
\text { Count }\end{array}$ & $\begin{array}{l}\text { Resources } \\
\text { Identified }\end{array}$ & $\begin{array}{l}\text { Appendix A } \\
\text { Figure }\end{array}$ & $\begin{array}{l}\text { Appendix B } \\
\text { Figure }\end{array}$ \\
\hline 29 & LSX-CO-018.000 & 0.12 & 1.98 & 538864.66 & 3561579.61 & 3 & & A11 & B29 \\
\hline 30 & LSX-CO-024.000 & 0.14 & 2.30 & 541590.03 & 3561039.37 & 5 & & $\mathrm{~A} 12$ & B30 \\
\hline 31 & LSX-CO-024.000 - LSX-CO-026.000 & 0.61 & 9.58 & 542253.27 & 3561001.68 & 13 & & $\mathrm{~A} 12$ & B31 \\
\hline 32 & LSX-CO-027.000, LSX-CO-028.000 & 0.27 & 4.84 & 543279.07 & 3560649.46 & 6 & & $\mathrm{~A} 12$ & B32 \\
\hline 33 & LSX-CO-028.000 & 0.30 & 6.06 & 543842.15 & 3560524.13 & 4 & & $\mathrm{~A} 12$ & B33 \\
\hline 34 & LSX-CO-030.000, LSX-CO-031.000 & 0.28 & 5.23 & 544941.40 & 3560259.53 & 9 & & $\mathrm{~A} 12$ & B34 \\
\hline 35 & LSX-CO-031.000, LSX-CO-032.000 & 0.37 & 5.65 & 545819.45 & 3560060.83 & 14 & & A13 & B35 \\
\hline 36 & LSX-CO-033.000 & 0.15 & 2.35 & 547073.90 & 3559769.69 & 2 & & $\mathrm{~A} 13$ & B36 \\
\hline 37 & LSX-CO-034.000 & 0.11 & 1.91 & 547376.99 & 3559695.86 & 5 & & $\mathrm{~A} 13$ & B37 \\
\hline 38 & LSX-ER-0005.000, LSX-ER-0007.000 & 0.26 & 5.08 & 551584.12 & 3558985.34 & 8 & & $\mathrm{~A} 14$ & B38 \\
\hline 39 & LSX-ER-0008.000, LSX-ER-0009.000 & 0.14 & 2.63 & 553047.97 & 3558354.78 & 8 & & $\mathrm{~A} 14$ & B39 \\
\hline 40 & LSX-ER-0010.000 & 0.17 & 3.02 & 553913.64 & 3558166.68 & 3 & & A15 & B40 \\
\hline 41 & LSX-ER-0010.000, LSX-ER-0011.000 & 0.24 & 4.10 & 554598.23 & 3558003.16 & 6 & & A15 & B41 \\
\hline 42 & LSX-ER-0011 1.000, LSX-ER-0012.000 & 0.33 & 5.65 & 555212.48 & 3557847.40 & 3 & & A15 & B42 \\
\hline 43 & LSX-ER-0013.000 - LSX-ER-0015.000 & 0.37 & 6.28 & 557276.29 & 3557320.74 & 9 & & A16 & B43 \\
\hline 44 & LSX-ER-0016.000 & 0.00 & 3.07 & 558180.76 & 3557090.10 & 3 & & A16 & B44 \\
\hline 45 & LSX-ER-0016.000, LSX-ER-0017.000 & 0.35 & 5.77 & 558768.25 & 3556944.10 & 7 & & A16 & B45 \\
\hline 46 & LSX-ER-0017.000 & 0.16 & 2.51 & 559994.83 & 3556636.74 & 4 & & A16 & B46 \\
\hline 47 & LSX-ER-0018.000 & 0.13 & 2.13 & 561010.99 & 3556370.80 & 7 & & A16 & B47 \\
\hline 48 & LSX-ER-0018.000 & 0.14 & 3.48 & 561292.41 & 3556289.10 & 4 & & $\mathrm{~A} 17$ & B48 \\
\hline 49 & LSX-ER-0018.000 - LSX-ER-0020.000 & 0.13 & 2.71 & 561568.11 & 3556354.84 & 11 & & $\mathrm{~A} 17$ & B49 \\
\hline 50 & LSX-ER-0025.000 & 0.41 & 7.01 & 564110.06 & 3555738.67 & 27 & & $\mathrm{~A} 17$ & B50 \\
\hline 51 & LSX-ER-0027.000 & 0.27 & 4.64 & 564792.11 & 3555561.60 & 15 & & $\mathrm{~A} 17$ & B51 \\
\hline 52 & LSX-ER-0030.000 - LSX-ER-0032.000 & 0.37 & 5.99 & 566310.30 & 3555245.76 & 18 & & A18 & B52 \\
\hline 53 & LSX-ER-0032.000 - LSX-ER-0034.000 & 0.76 & 12.46 & 567503.00 & 3555091.61 & 22 & & A18 & B53 \\
\hline 54 & LSX-ER-0036.000 & 0.18 & 3.48 & 568646.86 & 3554740.48 & 9 & & A18 & B54 \\
\hline 55 & LSX-ER-0037.000 & 0.13 & 2.07 & 568946.82 & 3554735.77 & 8 & & A18 & B55 \\
\hline 56 & LSX-ER-04 1.000 & 0.40 & 6.40 & 570446.41 & 3554539.13 & 34 & & A19 & B56 \\
\hline 57 & LSX-ER-0043.000 - LSX-ER-0045.000 & 0.33 & 6.17 & 571691.32 & 3553796.82 & 10 & & A19 & B57 \\
\hline
\end{tabular}




\begin{tabular}{|c|c|c|c|c|c|c|c|c|c|}
\hline $\begin{array}{c}\text { Permit Area } \\
\text { No. }\end{array}$ & Parcels & Miles & Acres & UTM E & UTM N & $\begin{array}{c}\text { Shovel Test } \\
\text { Count }\end{array}$ & $\begin{array}{l}\text { Resources } \\
\text { Identified }\end{array}$ & $\begin{array}{l}\text { Appendix A } \\
\text { Figure }\end{array}$ & $\begin{array}{l}\text { Appendix B } \\
\text { Figure }\end{array}$ \\
\hline 58 & LSX-ER-0045.000, LSX-ER-0046.000 & 0.14 & 2.80 & 572637.34 & 3553479.42 & 3 & & A19 & B58 \\
\hline 59 & LSX-ER-0048.000 & 0.12 & 2.32 & 573914.54 & 3553216.66 & 4 & & A20 & B59 \\
\hline 60 & LSX-ER-0049.000 & 0.19 & 3.25 & 574411.66 & 3553029.14 & 2 & & A20 & $\mathrm{B} 60$ \\
\hline 61 & LSX-ER-0049.000, LSX-ER-0050.000 & 0.39 & 6.00 & 575074.34 & 3552836.88 & 7 & & A20 & B61 \\
\hline 62 & LSX-ER-0049.000 & 0.31 & 4.92 & 575956.85 & 3552618.89 & 7 & & A20 & B62 \\
\hline 63 & LSX-ER-0053.000, LSX-ER-0054.000 & 0.35 & 5.86 & 577475.78 & 3552242.82 & 5 & & A21 & B63 \\
\hline 64 & LSX-ER-0054.000 - LSX-ER-0056.000 & 0.28 & 6.53 & 578000.05 & 3552019.45 & 9 & & A21 & B64 \\
\hline 65 & LSX-ER-0058.000 & 0.23 & 4.60 & 579264.19 & 3551696.41 & 4 & & A21 & B65 \\
\hline 66 & LSX-ER-0063.000 & 0.13 & 2.07 & 582070.32 & 3551096.08 & 5 & & A22 & B66 \\
\hline 67 & LSX-ER-0063.000 - LSX-ER-0065.000 & 0.11 & 2.42 & 582443.91 & 3551010.97 & 6 & & A22 & B67 \\
\hline 68 & LSX-ER-0064.000 & 0.23 & 3.64 & 583749.51 & 3550680.39 & 4 & & A22 & B68 \\
\hline 69 & LSX-ER-0064.000 & 0.17 & 2.65 & 584341.55 & 3550532.69 & 4 & & A22 & B69 \\
\hline 70 & LSX-ER-0067.000 & 0.23 & 3.64 & 585111.90 & 3550480.64 & 7 & & A23 & B70 \\
\hline 71 & LSX-ER-0069.000 & 0.21 & 3.32 & 586081.62 & 3550098.63 & 6 & & A23 & B71 \\
\hline 72 & LSX-ER-0069.000 & 0.11 & 1.81 & 586653.85 & 3549957.27 & 2 & & A23 & B72 \\
\hline 73 & LSX-ER-0069.000 & 0.23 & 4.00 & 587114.88 & 3549845.75 & 6 & & A23 & B73 \\
\hline 74 & LSX-ER-0071.000, LSX-ER-0072.000 & 0.39 & 6.67 & 588472.35 & 3549600.23 & 7 & & A23-A24 & B74 \\
\hline 75 & LSX-ER-0073.000 & 0.15 & 2.32 & 589033.52 & 3549560.65 & 4 & & A24 & B75 \\
\hline 76 & LSX-ER-0075.000, LSX-ER-0076.000 & 0.12 & 2.24 & 589869.57 & 3549380.97 & 3 & & A24 & B76 \\
\hline 77 & LSX-ER-0076.000, LSX-ER-0077.000 & 0.26 & 4.67 & 590284.61 & 3549369.66 & 11 & & $\mathrm{~A} 24$ & B77 \\
\hline 78 & LSX-ER-0078.000 & 0.12 & 2.13 & 590626.57 & 3549259.09 & 4 & & A24 & B78 \\
\hline 79 & LSX-ER-0079.000 & 0.11 & 1.83 & 591797.90 & 3548990.96 & 4 & & A24 & B79 \\
\hline 80 & LSX-ER-0080.000 - LSX-ER-0082.000 & 0.27 & 5.06 & 592457.65 & 3548872.00 & 12 & & A24 & B80 \\
\hline 81 & LSX-ER-0082.000, LSX-ER-0083.000 & 0.31 & 5.30 & 593045.34 & 3548778.42 & 12 & & A25 & B81 \\
\hline 82 & LSX-ER-0083.000 - LSX-ER-0085.000 & 0.14 & 2.24 & 593977.65 & 3548623.70 & 2 & & A25 & B82 \\
\hline 83 & LSX-ER-0085.000 - LSX-ER-0087.000 & 0.34 & 5.70 & 595321.02 & 3548395.02 & 8 & & A25 & B83 \\
\hline 84 & LSX-ER-0089.000 & 0.24 & 4.26 & 596461.62 & 3548198.64 & 8 & & A25 & B84 \\
\hline 85 & LSX-ER-0089.000 & 0.13 & 2.03 & 596999.79 & 3548113.64 & 2 & & A25 & B85 \\
\hline 86 & LSX-ER-0091.000, LSX-ER-0092.000 & 0.13 & 2.06 & 597832.78 & 3547971.71 & 3 & & A25 & B86 \\
\hline
\end{tabular}




\begin{tabular}{|c|c|c|c|c|c|c|c|c|c|}
\hline $\begin{array}{l}\text { Permit Area } \\
\text { No. }\end{array}$ & Parcels & Miles & Acres & UTM E & UTM N & $\begin{array}{c}\text { Shovel Test } \\
\text { Count }\end{array}$ & $\begin{array}{l}\text { Resources } \\
\text { Identified }\end{array}$ & $\begin{array}{l}\text { Appendix A } \\
\text { Figure }\end{array}$ & $\begin{array}{c}\text { Appendix B } \\
\text { Figure }\end{array}$ \\
\hline 87 & LSX-ER-0092.000 & 0.26 & 4.02 & 598503.11 & 3547861.07 & 8 & & A25 & B87 \\
\hline 88 & LSX-ER-0093.000 & 0.19 & 3.39 & 599051.43 & 3547764.09 & 7 & & A25 & B88 \\
\hline 89 & LSX-ER-0093.000, LSX-ER-0094.000 & 0.13 & 2.53 & 600156.49 & 3547575.45 & 7 & & A25 & B89 \\
\hline 90 & LSX-ER-0094.000 & 0.13 & 2.08 & 601083.98 & 3547417.38 & 3 & & A27 & B90 \\
\hline 91 & LSX-BQ-0002.000 & 0.15 & 2.42 & 602177.53 & 3547219.05 & 6 & & A27 & B91 \\
\hline 92 & LSX-BQ-0002.000 & 0.16 & 2.57 & 602601.43 & 3547138.77 & 5 & & A27 & B92 \\
\hline 93 & LSX-BQ-0003.000, LSX-BQ-0004.000 & 0.24 & 3.77 & 603613.42 & 3546970.84 & 5 & & A27 & B93 \\
\hline 94 & LSX-BQ-0005.000 & 0.20 & 3.51 & 604858.68 & 3546976.80 & 4 & & A28 & B94 \\
\hline 95 & LSX-BQ-0006.000, LSX-BQ-0007.000 thru LSX-BQ-0018.000 & 0.26 & 4.12 & 605629.12 & 3547145.14 & 7 & & A28 & B95 \\
\hline 96 & LSX-BQ-0007.000 thru LSX-BQ-0018.000 & 0.13 & 2.08 & 606181.08 & 3547269.16 & 2 & & A28 & B96 \\
\hline 97 & LSX-BQ-0007.000 thru LSX-BQ-0018.000 & 0.37 & 5.82 & 607047.25 & 3547376.77 & 5 & & A28 & B97 \\
\hline 98 & LSX-BQ-0007.000 thru LSX-BQ-0018.000 & 0.43 & 3.20 & 608407.70 & 3547582.89 & 3 & & A28 & B98 \\
\hline 99 & LSX-BQ-0007.000 thru LSX-BQ-0018.000 & 0.43 & 3.97 & 608737.32 & 3547633.52 & 7 & & A29 & B99 \\
\hline 100 & LSX-BQ-0007.000 thru LSX-BQ-0018.000 & 0.14 & 2.14 & 609371.48 & 3547738.16 & 3 & & A29 & B100 \\
\hline 101 & LSX-BQ-0007.000 thru LSX-BQ-0018.000 & 0.25 & 4.32 & 610140.54 & 3547800.88 & 9 & & A29 & B101 \\
\hline 102 & LSX-BQ-0007.000 thru LSX-BQ-0018.000 & 0.15 & 2.40 & 610710.05 & 3547830.71 & 3 & & A29 & B102 \\
\hline 103 & LSX-BQ-0007.000 thru LSX-BQ-0018.000 & 0.29 & 5.00 & UTM redacted & UTM redacted & 36 & $\begin{array}{c}\text { 41BQ358, } \\
\text { BQ-07-ISO- } \\
01\end{array}$ & A29 & B103 \\
\hline 104 & LSX-BQ-0007.000 thru LSX-BQ-0018.000 & 0.77 & 8.23 & 612026.37 & 3548189.40 & 27 & & A29 & B104 \\
\hline 105 & LSX-BQ-0007.000 thru LSX-BQ-0018.000 & 0.77 & 3.75 & 612594.66 & 3548282.51 & 4 & & A30 & B105 \\
\hline 106 & LSX-BQ-0007.000 thru LSX-BQ-0018.000 & 0.35 & 6.13 & 613540.50 & 3548563.82 & 9 & & $\mathrm{~A} 30$ & B106 \\
\hline 107 & LSX-BQ-0020.000, LSX-BQ-0021.000 & 0.15 & 2.44 & 616086.31 & 3548988.86 & 7 & & A30 & B107 \\
\hline 108 & LSX-BQ-0024.000 & 0.16 & 2.54 & 617648.37 & 3549174.27 & 3 & & A31 & B108 \\
\hline 109 & LSX-BQ-0031.000 - LSX-BQ-0036.000 & 0.59 & 12.48 & 619668.57 & 3549580.80 & 11 & & A31 & B109 \\
\hline 110 & LSX-BQ-0038.000 & 0.25 & 4.33 & 621909.66 & 3549406.23 & 4 & & A32 & B110 \\
\hline 111 & LSX-BQ-0038.000 & 0.24 & 4.20 & 622495.77 & 3549368.06 & 3 & & A32 & B111 \\
\hline 112 & LSX-BQ-0038.000 & 0.18 & 3.20 & 622949.58 & 3549347.30 & 4 & & A32 & B112 \\
\hline 113 & LSX-BQ-0038.000 & 0.28 & 4.76 & UTM redacted & UTM redacted & 12 & 41BQ359 & A32 & B113 \\
\hline 114 & LSX-BQ-0038.000, LSX-BQ-0042.000 / LSX-BQ-0043.000 & 0.25 & 4.59 & 625107.20 & 3549244.58 & 6 & & A33 & B1 14 \\
\hline
\end{tabular}




\begin{tabular}{|c|c|c|c|c|c|c|c|c|c|}
\hline $\begin{array}{c}\text { Permit Area } \\
\text { No. }\end{array}$ & Parcels & Miles & Acres & UTME & UTMN & $\begin{array}{c}\text { Shovel Test } \\
\text { Count }\end{array}$ & $\begin{array}{l}\text { Resources } \\
\text { Identified }\end{array}$ & $\begin{array}{l}\text { Appendix A } \\
\text { Figure }\end{array}$ & $\begin{array}{c}\text { Appendix B } \\
\text { Figure }\end{array}$ \\
\hline 115 & LSX-BQ-0042.000 / LSX-BQ-0043.000 & 0.13 & 2.01 & 625856.85 & 3549203.56 & 1 & & A33 & B115 \\
\hline 116 & LSX-BQ-0042.000 / LSX-BQ-0043.000 & 0.55 & 5.29 & 626684.01 & 3549152.32 & 7 & & A33 & B116 \\
\hline 117 & LSX-BQ-0042.000 / LSX-BQ-0043.000 & 0.55 & 3.66 & 627044.43 & 3549137.75 & 3 & & A33 & B117 \\
\hline 118 & LSX-BQ-0042.000 / LSX-BQ-0043.000 & 0.24 & 3.71 & 627615.59 & 3549111.83 & 3 & & A33 & B118 \\
\hline 119 & LSX-BQ-0044.000 thru LSX-BQ-0047.000 & 0.24 & 3.82 & 629083.34 & 3549045.69 & 3 & & A34 & B1 19 \\
\hline 120 & LSX-BQ-0044.000 thru LSX-BQ-0047.000 & 0.15 & 2.28 & 629896.31 & 3548991.35 & 2 & & A34 & B120 \\
\hline 121 & LSX-BQ-0044.000 thru LSX-BQ-0047.000 & 0.31 & 6.22 & 630346.17 & 3548953.76 & 3 & & A34 & B121 \\
\hline 122 & LSX-BQ-0048.000 / LSX-BQ-0049.000 & 0.12 & 1.93 & 631362.71 & 3548993.90 & 2 & & A34 & B122 \\
\hline 123 & LSX-BQ-0050.000, LSX-BQ-0051.000 & 0.34 & 8.39 & 633104.74 & 3548815.84 & 5 & & A35 & B123 \\
\hline 124 & LSX-BQ-0053.000 & 0.29 & 6.33 & 634262.27 & 3548860.72 & 5 & & A35 & B124 \\
\hline \multicolumn{2}{|r|}{ Total } & 32.81 & 518.60 & & & 901 & & & \\
\hline
\end{tabular}

Table 5-7. Newly Identified Resources within the Loop 3 Permit Areas.

\begin{tabular}{|c|c|c|c|c|c|c|c|c|c|c|}
\hline Trinomial & MP Begin & MP End & Site Type & $\begin{array}{l}\text { Cultural } \\
\text { Affiliation }\end{array}$ & Record Date & $\begin{array}{c}\text { Current Materials } \\
\text { Observed }\end{array}$ & $\begin{array}{l}\text { Current Eligibility } \\
\text { Recommendations }\end{array}$ & $\begin{array}{c}\text { Appendix A } \\
\text { Figure }\end{array}$ & $\begin{array}{l}\text { Appendix } \\
\text { B Figure }\end{array}$ & $\begin{array}{l}\text { Report } \\
\text { Figure } \\
\end{array}$ \\
\hline $41 B Q 358$ & 255.00 & 255.07 & Prehistoric lithic scatter & $\begin{array}{l}\text { Unknown } \\
\text { Prehistoric }\end{array}$ & 5/29/2019 & $\begin{array}{l}6 \text { pieces of chert } \\
\text { debitage. }\end{array}$ & Ineligible & A32 & B113 & $5-6$ \\
\hline BQ-07-ISO-01 & 255.10 & & Isolate & $\begin{array}{c}\text { Late to } \\
\text { Transitional } \\
\text { Archaic / } \\
\text { Prehistoric }\end{array}$ & $5 / 29 / 2019$ & $\begin{array}{l}\text { Ellis or Godley type } \\
\text { projectile point. }\end{array}$ & Ineligible & A29 & B103 & $5-6$ \\
\hline
\end{tabular}

Table 5-8. Newly Identified Resources outside of Loop 3 Permit Areas.

\begin{tabular}{|c|c|c|c|c|c|c|c|c|c|c|}
\hline Trinomial & MP Begin & MP End & Site Type & $\begin{array}{l}\text { Cultural } \\
\text { Affiliation }\end{array}$ & Record Date & $\begin{array}{c}\text { Current Materials } \\
\text { Observed }\end{array}$ & $\begin{array}{l}\text { Current Eligibility } \\
\text { Recommendations }\end{array}$ & $\begin{array}{c}\text { Appendix } \mathrm{A} \\
\text { Figure } \\
\end{array}$ & $\begin{array}{l}\text { Appendix } \\
\text { B Figure }\end{array}$ & $\begin{array}{l}\text { Report } \\
\text { Figure }\end{array}$ \\
\hline 41BQ359 & 263.52 & & Prehistoric lithic scatter & $\begin{array}{l}\text { Unknown } \\
\text { Prehistoric }\end{array}$ & $5 / 29 / 2019$ & $\begin{array}{l}1 \text { chert biface and } \\
5 \text { flakes. }\end{array}$ & Ineligible & A29 & B103 & $5-13$ \\
\hline
\end{tabular}




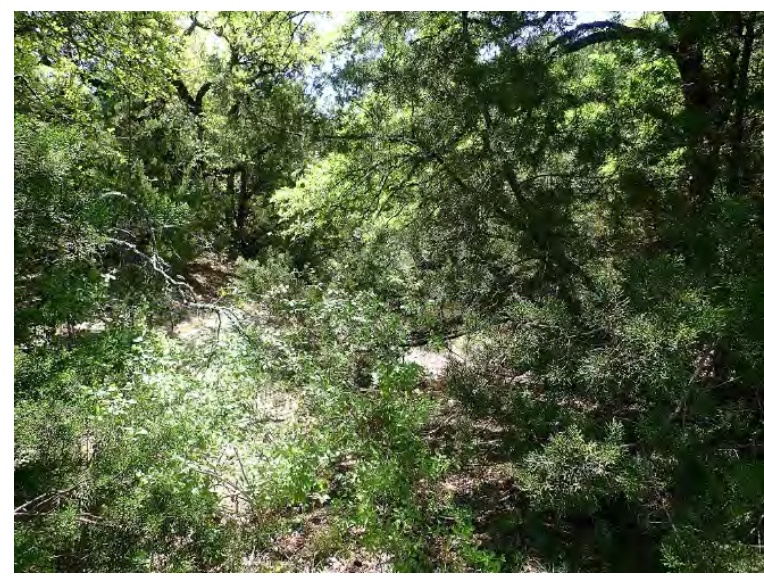

Figure 5-2. Overview of typical field conditions observed within wooded areas of Loop 3. View is to the south.

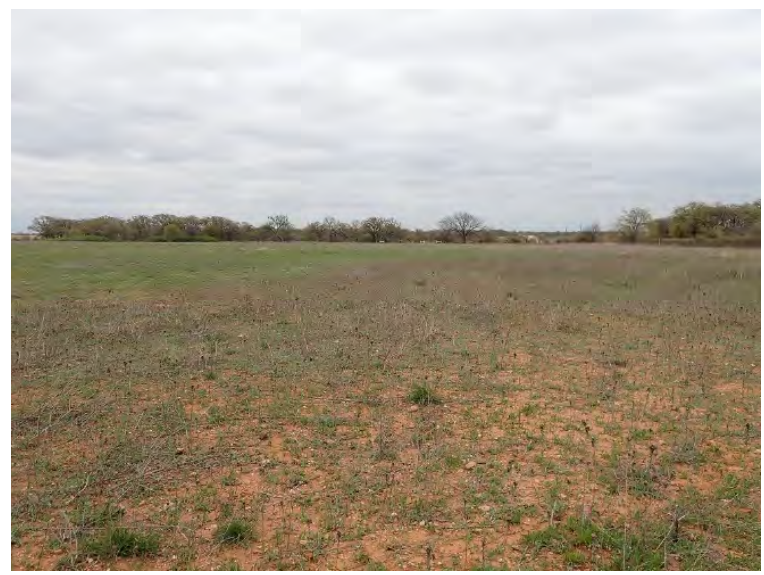

Figure 5-3. Overview of typical field conditions observed within disturbed areas of Loop 3 where subsoil was visible on the surface. View is to the northeast.

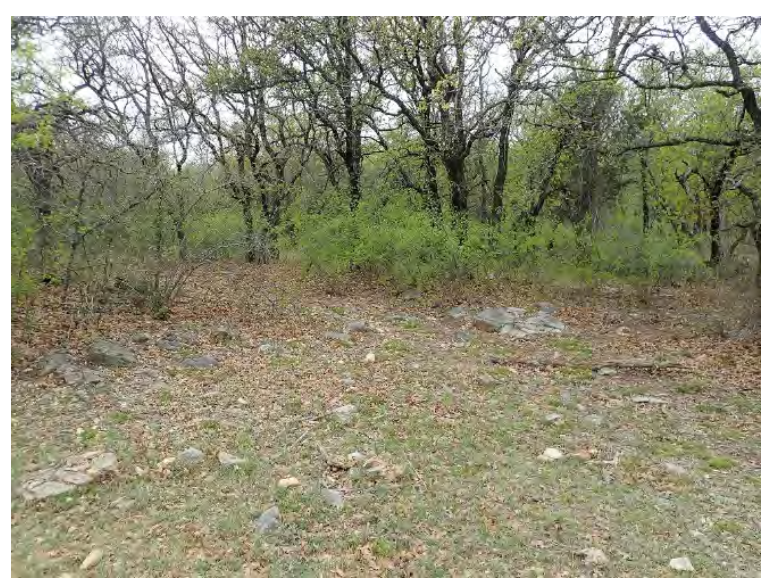

Figure 5-4. Exposed bedrock as seen within the survey corridor. View is to the northwest.

\subsubsection{Newly Identified Resources within Permit Areas}

Three new resources were identified as a result of survey within the jurisdictional permit areas of Loop 3. These are described below.

\subsubsection{Resource 41BQ358}

Resources 41BQ358 was identified by Gray \& Pape on April 3, 2019. The resource is located in Bosque County, Permit Area Number 103, approximately 170 meters (558 feet) south of the Bosque River, to the west of a tributary drainage leading to the river. The APE at the location measures between 40 and 55 meters (131 and 180 feet) wide, with approximately 30 to 45 meters (100 to 148 feet) of that width within an existing pipeline ROW. Resource 41BQ358 occupies a nearly level terrace or bench at the bottom of a steeply sloped hillside. The hillside is largely composed of exposed fossil rich limestone. At the base of the hill, the APE is covered in short grasses bordered by low-lying juniper and cypress trees, yielding good surface visibility (Figure 55). Resource 41BQ358 consists of a sparse surface and subsurface lithic scatter, dispersed along the edge of the west-facing side slope between the base of the existing pipeline corridor and the edge of the adjacent waterway to the south (Figure 5-6).

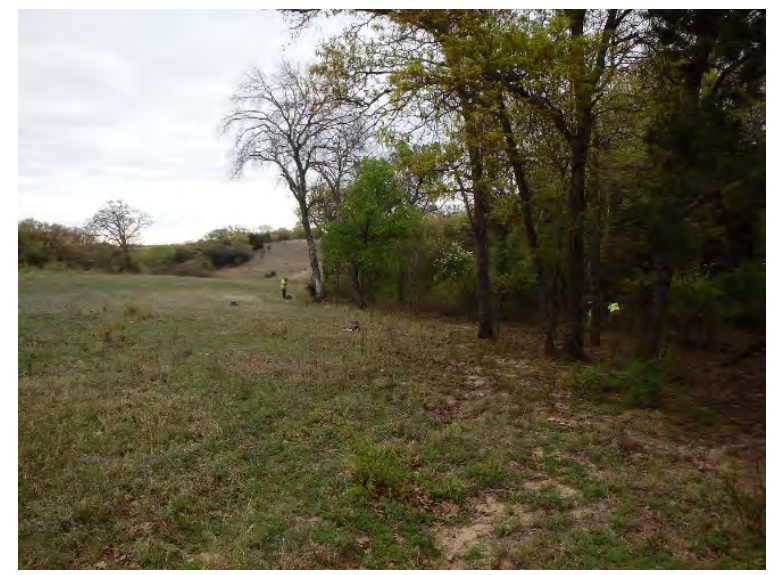

Figure 5-5. Overview of the location of Resource $41 \mathrm{BQ} 358$ within the APE. View is to the northeast. 
REMOVED FROM PUBLIC COPY

Plan view of Resources 41BQ358 and BQ-07-ISO-01. 
Investigation of the resource began with the identification of single flake in Shovel Test T7 during survey of the Permit Area (Figure 5-6). Delineation consisted of an additional 20 shovel tests excavated at 10-meter (33-foot) intervals within the APE. Shovel test delineation of the site did not continue to the north as this portion of the APE consists of slope of approximately 30 degrees and contains potentially shallowly buried pipelines. However, this area was surface inspected as part of delineation efforts and during survey of the APE in general. Subsoil and bedrock were observed on the surface of the northern portion of the APE. Likewise, the area of APE to the south of the site boundary within a distance of approximately 3 meters (10 feet) or less of the southern-most conducted tests drops off into a wide natural drainage and no shovel testing could be performed there. These areas were surface inspected however as part of delineation efforts. Shovel testing resulted in 3 positive shovel tests total. These tests contained four pieces of chert debitage (Figure 5-7; Tables 5-9 and 5-10).

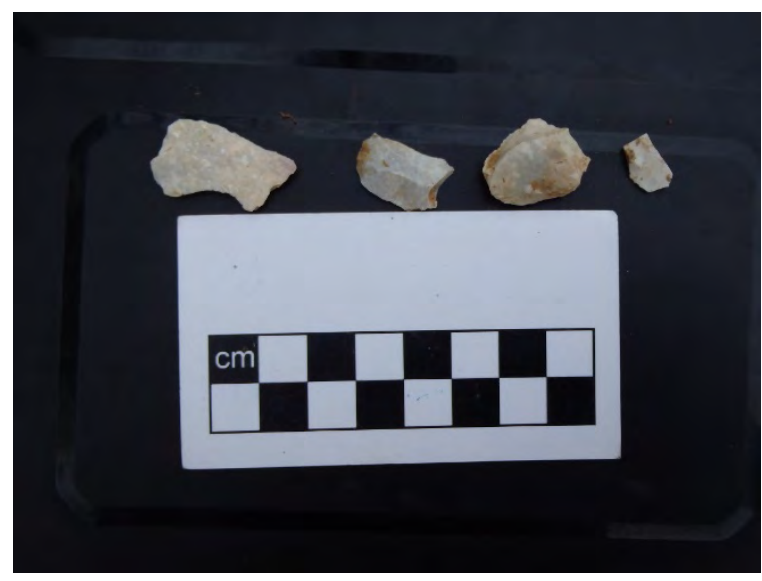

Figure 5-7. Representative materials identified within Resource 41BQ358.

Pedestrian walkover of the location resulted in the identification of six additional pieces of chert debitage on the surface having eroded from the bank of the drainage to the south of the landform.
Table 5-9. Provenience of Subsurface Materials Identified within Resource 41BQ358.

\begin{tabular}{|c|c|c|}
\hline Test Number & Material & Depth \\
\hline T7 & 1 chert flake & $28 \mathrm{~cm}$ \\
\hline$T 7 b$ & 2 chert flakes & $20 \mathrm{~cm}$ \\
\hline $\mathrm{T} 7 \mathrm{~d}$ & 1 chert flake & $28 \mathrm{~cm}$ \\
\hline
\end{tabular}

Table 5-10. Artifact Assemblage Observed at $41 \mathrm{BQ} 358$.

\begin{tabular}{|c|c|c|}
\hline Depth & Flakes & FCR \\
\hline Surface & 7 & 25 \\
\hline $0-10$ & - & - \\
\hline $10-20$ & 2 & - \\
\hline $20-30$ & 2 & - \\
\hline $30-40$ & - & - \\
\hline $40-50$ & - & - \\
\hline
\end{tabular}

All materials were composed of gray/white fine-grained Edwards chert. The debitage were indicative of late stage reduction. No diagnostic artifacts or more developed tools were identified to the west of the water way; however, a nearby artifact recorded as an isolate, $\mathrm{BQ}-07-\mathrm{ISO}-01$, is potentially associated with the site and is discussed separately below.

The site was revisited by Gray \& Pape and representatives of the USACE on October 29, 2019. During a walk over of the site, the USACE representative observed $25 \mathrm{FCR}$ of limestone scattered inside the western portion of the site boundary in two small loose clusters. The location of the FCR is at the bottom of the slope. This suggests the current location of the FCR is the result of colluvial action and is thus out of context. Three flakes were observed on the surface including one large blade or blade-like flake of likely heat-treated white chert. The waterway below the site was observed to be flowing during the site visit with a series of deep clear pools with a limestone stream bottom. The deep stream pools might be seep/spring perennial pools. 
The resultant resource boundary within the corridor measures approximately 130 meters (429 feet) east-west by 40 meters (131.23 feet) north-south at its widest point. Soil mapped for most of the area consists of Brackett-Eckrant association, while soil in the western portion of the resource consists of Purves-Maloterre association (NRCS 2019). Purves, Maloterre, and Eckrant are all very shallow soils which encounter coarsely fractured indurated limestone bedrock at roughly 30 to 36 centimeters (12 to 14 inches) deep. Only the Brackett series extends deeper, with a C horizon of weakly cemented, fractured and weathered limestone bedrock that extends to 152 centimeters (60 inches). Many shovel tests indicated disturbed soils particularly along the north of the APE due to existing pipelines, as well as from prior terracing activities and erosion. Many radial tests were either visibly disturbed from recent pipeline activities (to the north) or on steep slope of 30 degrees or more (to the south). Soils at the site were found to be shallow, with a typical shovel test profile within the resource/APE consisting of a surface layer of brown or dark yellowish brown (10YR 4/3 to $5 / 3$ or $4 / 6$ ) loamy sand to a depth of 28 centimeters (11.02 inches) followed by yellowish red (5YR 4/6) loamy sand to a depth of between 25 and 40 centimeters (10 and 16 inches) overlying limestone bedrock (Appendix C). Fragments of limestone and other nonculturally modified rock were present throughout the profile. This profile most closely represents the $A k, B k$, and $R$ horizons of the Purves series.

Shovel tests at the resource produced shallow soil profiles that appeared deflated. Due to previous pipeline work in the APE and sloping landscape, it is possible that the observed soils and artifacts have eroded downslope to their current location. The surface finds within the site were out of context and had no discernable provenience. Within the APE, the resource areas appear to have experienced moderate erosion and deflation due to previous impacts. The location is spatially limited by the surrounding topography and previous disturbance. This observation combined with the sparsity of artifacts and shallow soils recorded during the current effort suggests the resource within the ROW is not significant. The resource does not retain the potential to provide significant research value and is thus recommended not eligible for the National Register, under Evaluation Criterion D.

\subsubsection{Resource BQ-07-ISO-01}

Isolate BQ-07-ISO-01 is located approximately 50 meters (164.04 feet) east of Resource 41BQ358, on the opposite side of the drainage that forms the eastern border of 41BQ358 (Figure 5-6). The isolate is located within a small area that represents the highest point on the surrounding landscape, overlooking waterways to the west, south, and east. From this point the landscape slopes downward in all directions. The undisturbed portion of this landform is limited due to the adjacent pipelines. The find is considered an isolate due to the lack of additional materials in the immediate surroundings however the proximity to $41 \mathrm{BQ} 358$ suggests the resources may be associated. The find is located in a recently cleared portion of the pipeline corridor with clumps of short grasses offering excellent surface visibility (Figure 5-8). The APE at the location measures between 40 and 55 meters (131 and 180 feet) wide, with approximately 30 to 45 meters (100 to 148 feet) of that width within an existing pipeline ROW.

The isolate consists of a projectile point identified in a shovel test at a depth of 28 centimeters (11.02 inches), just 2 centimeters (0.8 inches) above bedrock. The object consists of a triangular blade with a serrated straight left edge and slightly excurvate right edge, with prominent shoulders, straight base, expanding stem and random flaking pattern (Figure 5-9). The maximum length of the object is 40 millimeters (1.57 inches) with a width of 23 millimeters (0.9 inches) at the shoulders. The length of the stem is 11 
millimeters (0.4 inches) and the width of the stem is 15 millimeters ( 0.6 inches).

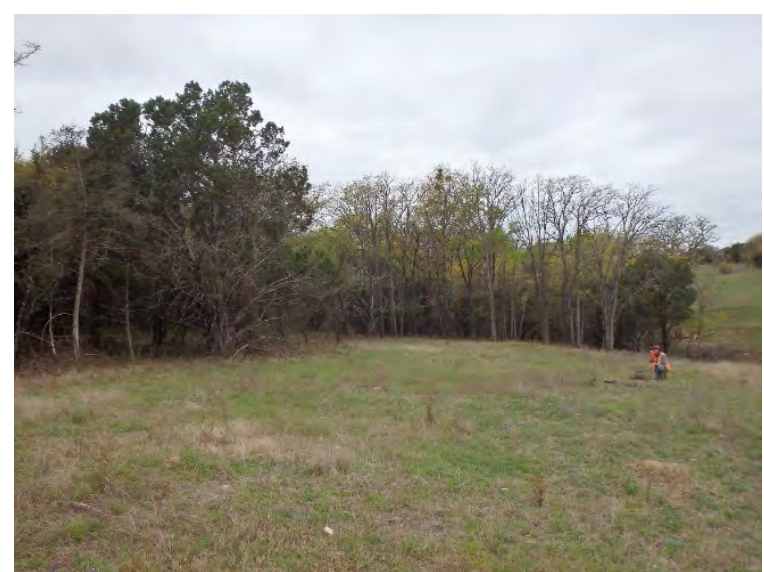

Figure 5-8. Overview of the location of Isolate BQ$01-1 S O-01$. View is to southwest

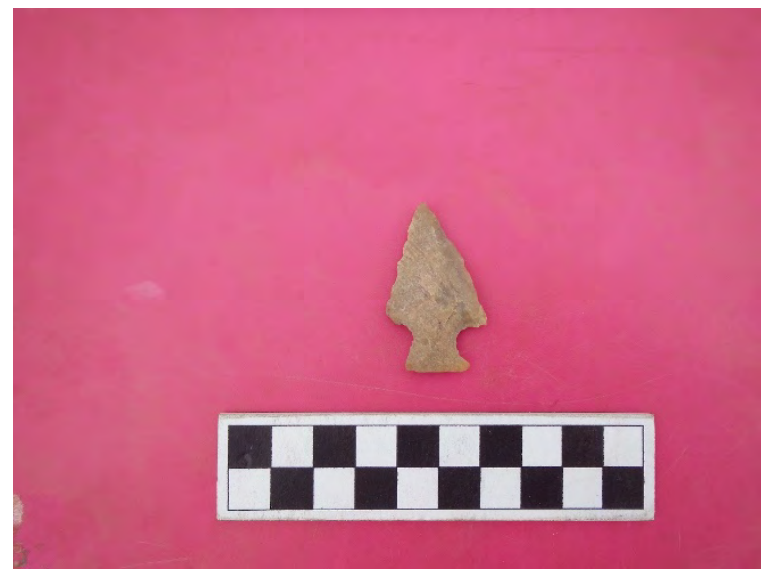

Figure 5-9. Projectile point which comprises Isolate BQ-01-ISO-01.

While there are several dart points in Texas that share many of these attributes, the overall characteristic of the find places it most similar to an Ellis or Godley type, both of which date from the Late to Transitional Archaic, although some Godley points have been found in Late Prehistoric contexts as well. The Ellis point has a distribution primarily in northcentral to northeast Texas, but it has also been reported in south and central Texas, the Panhandle, and Trans-Pecos. The Godley point has a distribution in the Brazos River drainage with occurrences in East Texas and Lovisiana (Turner et al. 2011).
Investigation of the isolate consisted of pedestrian walkover and six delineation shovel tests placed around the find at 10-meter (33foot) intervals within the APE (Figure 5-6). No shovel tests were conducted in the northern portion of the APE where the ground slopes sharply (30 degrees or more) down and is occupied by potentially shallowly buried pipelines, however this area was surface inspected as part of delineation efforts and during survey of the APE in general. Subsoil and bedrock were observed on the surface of the area. Likewise, the southern portion of the APE sloped sharply (30 degrees or more) downward into the banks of the adjacent waterway. No additional shovel tests were positive for cultural materials. Soils mapped for the location consist of the Brackett-Eckrant association, hilly. Eckrant soils area very shallow and encounter coarsely fractured indurated limestone bedrock at roughly 30 centimeters (12 inches) deep. The Brackett series extends deeper, with a $C$ horizon of weakly cemented, fractured and weathered limestone bedrock that extends to 152 centimeters (60 inches). The soils at the location, just as at 41BQ358, are quite shallow. Many shovel tests displayed previous disturbance exhibited as shallow soils (Appendix C). A typical shovel test profile at the location consists of brown to yellowish brown (1OYR 4/3 to 5/6) silt loam depth of between 10 and 40 centimeters $(4$ and 16 inches) overlying cemented limestone / bedrock.

The isolate is located within a small area that is spatially limited by the surrounding topography and previous disturbances. Further, the soils are quite shallow, showing signs of deflation and bedrock near the surface. The resource is not recommended for further work. The isolate does not contain additional materials with the potential to provide significant research value and is thus recommended not eligible for the National Register, under Evaluation Criterion D. 


\subsubsection{Resource 41BQ359}

Site 41BQ359 was identified by Gray \& Pape on April 17, 2019. The resource is located in Bosque County approximately 0.06 kilometers (0.03 miles) west of Cox Branch. The resource was initially identified within the APE, but the workspace has been revised to avoid the resource by 5.5 meters (18 feet), thus removing it from the permitted area. At the time of survey, the location was a recently plowed field covered by short grasses with excellent surface visibility (Figure 5-10). The resource was identified by a surface scatter of prehistoric lithics. Observed surface material includes one biface, one tested cobble, one core, two primary or secondary flakes, and five late stage reduction flakes, one of them edgedamaged (Figures 5-11 and 5-12, Table 511). Nearly all materials were composed of brown to gray/white chert of most likely an Edwards or Georgetown variety with one or two objects composed of an undetermined material potentially derived from river gravels. No diagnostic artifacts were identified.

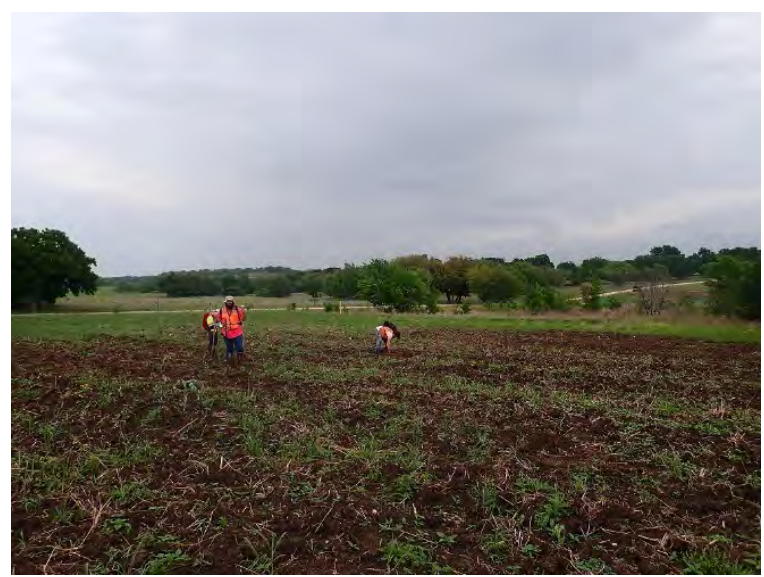

Figure 5-10. Overview of the location of Resource 41BQ359. View is to the northeast.

Investigation of the resource consisted of a systematic surface inspection and shovel testing. Due to the small size and relative concentration of the artifacts, only one shovel test was placed within the center of the scatter and five delineation shovel tests were placed around the visible limits of the surface scatter at 10-meter (33-foot) intervals to confirm the site limits (Figure 5-13).

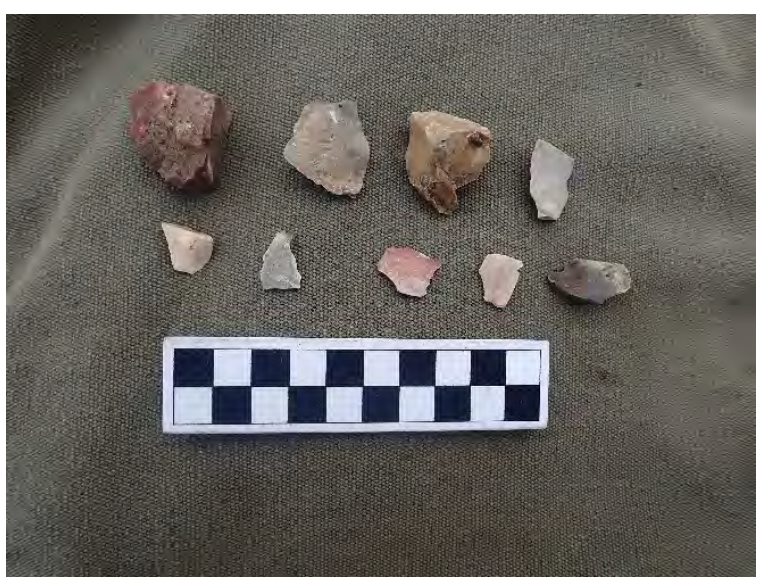

Figure 5-11. Representative lithics identified within Resource 41BQ359.

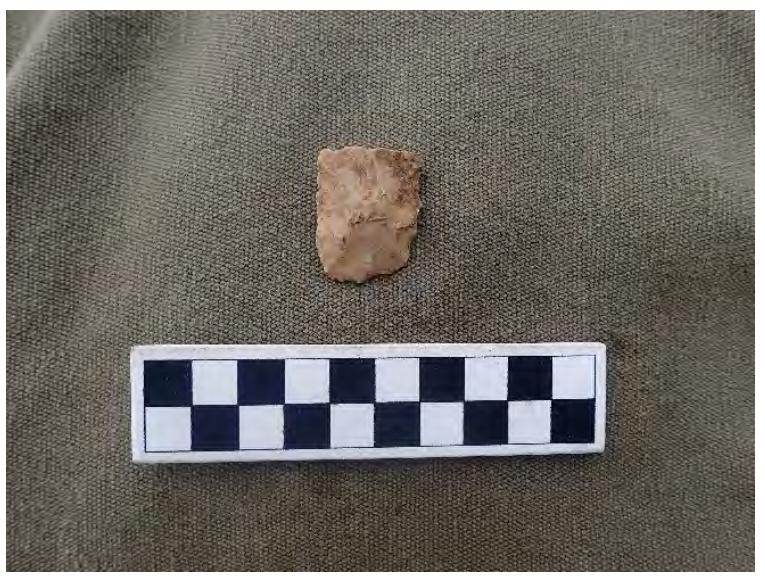

Figure 5-12. Biface observed on the surface at Site $41 B Q 359$.

Table 5-11. Artifact Assemblage Observed at $41 \mathrm{BQ} 359$.

\begin{tabular}{|c|c|c|c|c|}
\hline Depth & Flakes & Bifaces & Cores & $\begin{array}{c}\text { Tested } \\
\text { Cobble }\end{array}$ \\
\hline Surface & 7 & 1 & 1 & 1 \\
\hline $0-10$ & - & - & - & - \\
\hline $10-20$ & - & - & - & - \\
\hline $20-30$ & - & - & - & - \\
\hline $30-40$ & - & - & - & - \\
\hline $40-50$ & - & - & - & - \\
\hline
\end{tabular}

Of six shovel tests conducted within and around the scatter, none were positive for buried cultural materials. 
REMOVED FROM PUBLIC COPY

Plan view of Resource 41BQ359. 
No additional testing was performed within the field due to the plowed conditions, excellent surface visibility, and shallow soils observed by the conducted shovel tests. The resultant resource boundary within the corridor measures approximately 17 meters $(55.77$ feet) north-south by 9.5 meters (31.17 feet) east-west. The resource was not pursued to the north where a number of existing pipelines area present, however this area was surface inspected as part of delineation efforts and during survey of the APE in general. Subsoil was observed at the surface within the existing ROW. Soils mapped for the location consist of Slidell clay (NRCS 2019). Being located within a heavily plowed agricultural field, soil profiles appeared extremely deflated and represented the Bss and Bkssl horizons of the Slidell soil series. A typical shovel profile within the resource/APE consists of a shallow surface layer of 1OYR 3/1 silt loam to a depth of 10 centimeters ( 4 inches) followed by a 10YR $4 / 3$ silt clay loam to a depth of 40 centimeters (16 inches) (Appendix C). Besides the deflated nature of the soils and surface expression of the artifacts, the site's location in the corner of the ag field where machinery will make turns and soils often get pushed adds more doubt to the materials context.

The resource will be avoided by the project workspace. The resource is characterized by a sparsity of surface artifacts, lack of diagnostic artifacts, lack of subsurface materials, and deflated soils. The resource is not likely to add to the knowledge of prehistoric occupation of the area and is not recommended for further work. The site does not retain the potential to provide significant research value and is thus recommended not eligible for the National Register, under Evaluation Criterion D.

\subsubsection{Previously Recorded Resources Not Re-Identified}

Of the four previously recorded resources within 91 meters (300 feet) of the APE (41ER48, 41ER49, 41ER50, and 41ER56), none were re-identified by the current field effort (Table 5-12). One of these, 41ER48, is within the APE within a jurisdictional area. The remaining three are outside of the Project APE.

\subsubsection{Resource 41ER48}

Resource 41 ER48 was identified by Horizon in 2011 as part of the CREZ Lone Star Transmission Line Project (Cochran et al. 2012). The site consisted of a historic farmstead located approximately 1.9 kilometers (1.28 miles) northwest of the intersection of FM 1824 and CR 229. The site occupies a hill/ridgetop adjacent to Turkey Branch Creek. The resource was investigated by pedestrian survey and shovel testing. According to the site record, the site consists of a moderate to high-density of historic-era artifact scatter and the remnants of several historic-era structures including: one standing chimney composed of cut limestone and mortar, a dilapidated barn; two side-by-side corn-crib log structures, one possible collapsed-in cellar; one limestone wall structure along the terrace just north of the house structure; one collapsed windmill; and one fenced-in corral area with a corrugated metal door. The survey also recorded 10 pet (likely dog) graves, with four limestone markers and one informal headstone. Recorded artifacts consisted of $30+$ pieces of whiteware, $50+$ clear, blue, brown and milk glass fragments, 20+ clear, brown, and blue glass bottles of various sized, $5+$ clear glass jars, $15+$ metal fragments, 2 metal stoves, $30+$ wooden planks, $10+$ red cherry bricks and brick fragments, $3+$ window or door hinges, and $5+$ pieces of metal piping and farm equipment. The resource was considered by Horizon to possess little research value and no further work was recommended. The resource was determined ineligible for the NRHP in 2012 (THC 2019).

A small northern corner portion of Site 41 ER48 is mapped within Permit Area 74 of the current APE. This location was investigated Gray \& Pape on April 8, 2019 by pedestrian survey and shovel testing. At least five existing 
Table 5-12. Previously Recorded Resources Not Re-Identified within the APE.

\begin{tabular}{|c|c|c|c|c|c|c|c|c|c|c|c|c|}
\hline Trinomial & MP & JD* & Site Type & Cultural Affiliation & $\begin{array}{c}\text { Previous Materials } \\
\text { Observed }\end{array}$ & Record Date & $\begin{array}{l}\text { Previous } \\
\text { NRHP } \\
\text { Status } \\
\end{array}$ & $\begin{array}{l}\text { NRHP } \\
\text { Review } \\
\text { Date }\end{array}$ & $\begin{array}{l}\text { Current } \\
\text { Materials } \\
\text { Observed }\end{array}$ & $\begin{array}{l}\text { Current Eligibility } \\
\text { Recommendations }\end{array}$ & $\begin{array}{l}\text { Appendix } \\
\text { A Figure }\end{array}$ & $\begin{array}{l}\text { Report } \\
\text { Figure }\end{array}$ \\
\hline $41 E R 48$ & 240.66 & Yes & $\begin{array}{l}\text { Historic-era } \\
\text { Farmstead }\end{array}$ & $\begin{array}{l}\text { Early to Mid-20th } \\
\text { century }\end{array}$ & $\begin{array}{l}\text { Historic artifact } \\
\text { scatter, several } \\
\text { structures, and farm } \\
\text { equipment, } 5 \text { graves } \\
\text { of pets }\end{array}$ & $11 / 29 / 2011$ & Ineligible & $4 / 16 / 2012$ & $\mathrm{~N} / \mathrm{A}$ & $\begin{array}{c}\text { Not Located } \\
\text { within the APE. } \\
\text { No Further Work }\end{array}$ & A23-A24 & $5-13$ \\
\hline 41ER49 & Offline & No & Historic scatter & $\begin{array}{l}\text { Early to Mid-20th } \\
\text { century }\end{array}$ & $\begin{array}{l}\text { 6+ pieces of } \\
\text { whiteware, } 1 \text { brown } \\
\text { glass bottle base, } 1 \\
\text { fragment of spun } \\
\text { yarn, } 1 \text { blue-green } \\
\text { glass shard }\end{array}$ & $11 / 28 / 2011$ & $\begin{array}{l}\text { Ineligible } \\
\text { within } \\
\text { ROW }\end{array}$ & $5 / 2 / 2012$ & $\mathrm{~N} / \mathrm{A}$ & $\begin{array}{c}\text { Not Located } \\
\text { within the APE. } \\
\text { No Further Work }\end{array}$ & A24 & $5-16$ \\
\hline 41ER50 & Offline & No & $\begin{array}{l}\text { Prehistoric } \\
\text { lithic scatter } \\
\text { and historic- } \\
\text { era surface } \\
\text { scatter }\end{array}$ & $\begin{array}{l}\text { Early to Mid-20th } \\
\text { century, Unknown } \\
\text { Prehistoric }\end{array}$ & $\begin{array}{l}1 \text { oxidized metal } \\
\text { hinge, } 1 \text { oxidized } \\
\text { metal saw blade, } 1 \\
\text { piece of whiteware, } \\
1 \text { thick brown glass } \\
\text { bottle base, } 1 \\
\text { worked chert flake. }\end{array}$ & $11 / 30 / 2011$ & $\begin{array}{l}\text { Ineligible } \\
\text { within } \\
\text { ROW }\end{array}$ & $4 / 16 / 2012$ & $\mathrm{~N} / \mathrm{A}$ & $\begin{array}{c}\text { Not Located } \\
\text { within the APE. } \\
\text { No Further Work }\end{array}$ & A24 & $5-18$ \\
\hline $41 \mathrm{ER} 56$ & Offline & No & $\begin{array}{l}\text { Prehistoric } \\
\text { lithic scatter } \\
\text { and historic- } \\
\text { era surface } \\
\text { scatter }\end{array}$ & $\begin{array}{l}\text { Early to Mid-20th } \\
\text { century, Unknown } \\
\text { Prehistoric }\end{array}$ & $\begin{array}{l}1 \text { chert tertiary flake, } \\
1 \text { chert tool } \\
\text { fragment, } 4+\text { pieces } \\
\text { of whiteware } \\
\text { belonging to the } \\
\text { same object. }\end{array}$ & 1/17/2012 & $\begin{array}{l}\text { Ineligible } \\
\text { within } \\
\text { ROW }\end{array}$ & $5 / 3 / 2012$ & $\mathrm{~N} / \mathrm{A}$ & $\begin{array}{c}\text { Not Located } \\
\text { within the APE. } \\
\text { No Further Work }\end{array}$ & $\mathrm{A} 17$ & $5-19$ \\
\hline
\end{tabular}

$* \mathrm{JD}=$ Jurisdictional 
pipelines cross the mapped resource boundary in this area. The vicinity of the site was found to be largely inundated with standing water (Figure 5-14). No cultural materials were identified on surface at the location. Two shovel tests (bb4 and bb5) spaced 30 meters (100 feet) apart placed within and adjacent to the mapped boundary contained disturbed soils (Figure 5-15; Appendix C). No cultural materials were identified in the shovel tests. Soils mapped for the location consist of Windthorst fine sandy loam, 1 to 5 percent slopes, eroded. These soils are characterized by a shallow A horizon of grayish brown (10YR $5 / 2$ ) very fine sandy loam to a depth of 10 centimeters (4 inches). This is followed an $E$ horizon of light yellowish brown (10YR 6/4) very fine sandy loam. Below that are several $B$ horizons of red (2.5YR 4/6), yellowish red (5YR $5 / 6)$, and mottled brownish yellow (10YR 6/6) and strong brown (7.5YR 5/6) sandy clay down to 1 meter (39 inches) below surface (NRCS 2019). Shovel tests at the location contained of subsoil of mottled dark grayish brown (10YR 4/3) and reddish brown (2.5YR $4 / 3$ ) silty clay.

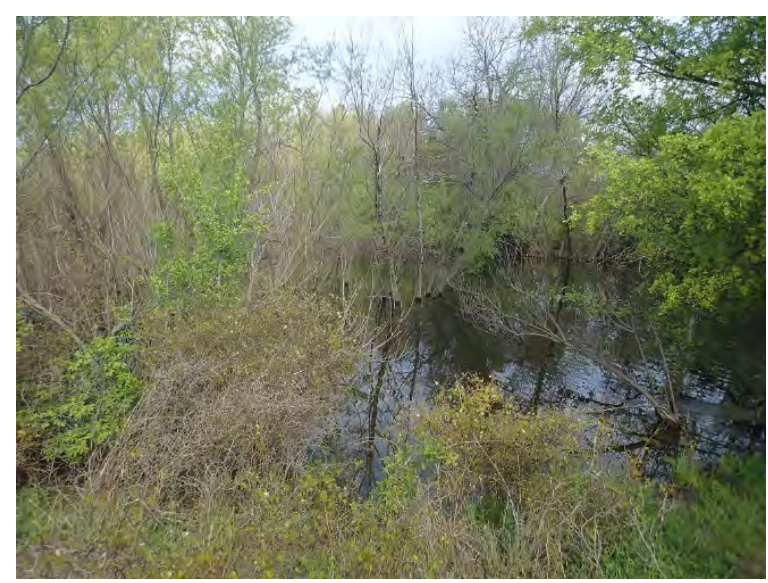

Figure 5-14. Mapped location of Resource 41 ER48 within the Loop 3 corridor. View is to the west.

The site was revisited by Gray \& Pape and representatives of the USACE on October 29, 2019. During a walk over of the site, the USACE representative observed a modern Tpost and hog panel pen was observed along the edge of the proposed ROW but no features recorded as part of $41 E R 48$ appear to be in close proximity to the proposed ROW. A review of the site map recorded by Horizon (Cochran et al. 2012) confirms that all features associated with the resource are located south of the existing pipeline ROW and will not be impacted by the current project (Figure 5-15). No further work needs were identified by USACE at site 41 ER48.

\subsubsection{Resource 41ER49}

Resource 41ER49 was identified by Horizon in 2011 as part of the CREZ Lone Star Transmission Line Project (Cochran et al. 2012). The site was recorded as a historic scatter and low limestone wall located partly in a cultivated field approximately 50 meters (164 feet) west of FM 1824 and approximately 100 meters (328 feet) south of the historic Duffau schoolhouse in Erath County. The location is adjacent to a small unnamed tributary of Duffau Creek which passes approximately 50 meters (164 feet) to the south. According to the site record, the site consists of a low density of both surface and subsurface historic-era artifacts. Within the ROW, surface artifacts were reported to include: $6+$ pieces of whiteware, one brown glass bottle base, one fragment of spun yarn, and one blue-green glass shard. Subsurface artifacts were encountered within the plow zone. Cultural material can be found along the surface to the north and northwest leading to the historic Duffau schoolhouse. A small red brick storage shed, and evidence of other bulldozed structures were also observed in the nearby vicinity of the site. Due to the disturbance of the site from agriculture, the resource was considered by Horizon to possess little research value and no further work was recommended. In 2012, the resource was determined ineligible for the NRHP within the ROW (THC 2019). 
REMOVED FROM PUBLIC COPY

Plan view of Resource 41 ER48. 
The portion of APE, Permit Area Number 80, that passes the previously recorded location of Resource 41 ER49 was surveyed by Gray \& Pape on April 5, 2019. The APE at the location measures approximately 40 meters (131 feet) wide, of which about 20 meters (66 feet) is within an existing pipeline ROW. The ROW is covered by short grass allowing good surface visibility. The remainder of the APE to the south contains scattered trees and grass but still offers good surface visibility (Figure 516). The site is located approximately 45 meters (148 feet) north of the current APE at Permit Area 80 (Figure 5-17). At least five existing pipelines and a transmission corridor are located between the previously recorded site and the current APE.

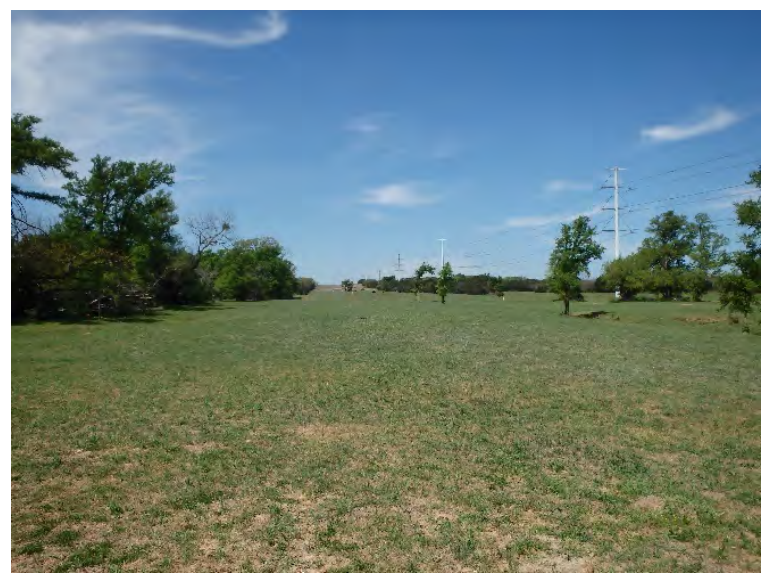

Figure 5-16. Overview of the APE where it passes near the previously recorded location of Resource 41 ER49. View is to the west.

The APE at the location was investigated by pedestrian survey and shovel testing with tests spaced 20 to 30 meters (66 to 100 feet) apart. Of five shovel tests placed within the APE, none were positive for cultural materials. Soils mapped for the location consist of Windthorst fine sandy loam, 1 to 5 percent slopes, eroded. These soils are characterized by a shallow A horizon of grayish brown (10YR 5/2) very fine sandy loam to a depth of 10 centimeters ( 4 inches). This is followed an $E$ horizon of light yellowish brown (10YR 6/4) very fine sandy loam. Below that are several $B$ horizons of red (2.5YR 4/6), yellowish red (5YR
5/6), and mottled brownish yellow (10YR 6/6) and strong brown (7.5YR 5/6) sandy clay down to 1 meter (39 inches) below surface (NRCS 2019). Shovel tests at the location contained mottled dark grayish brown (10YR 4/2) and reddish brown 2.5YR 4/3 silty clay (Appendix C).

No portion of the previously recorded resource appears to be located within the current APE and no further work is recommended for the location.

\subsubsection{Resource 41ER50}

Resource 41 ER50 was identified by Horizon in 2011 as part of the CREZ Lone Star Transmission Line Project (Cochran et al. 2012). The site was recorded as a multicomponent scatter of prehistoric and historic materials. The site is located approximately 1 kilometer (0.6 miles) southwest of the intersection of FM 2481 and FM 1824 in Duffau, Texas. The site is located on a gentle east and southeast trending slope about 110 meters (361 feet) north of an unnamed tributary of Duffau Creek. According to the site record, the site consists of a low density of surface historic-era and prehistoric artifacts. Observed surface materials consist of one oxidized metal hinge, one oxidized metal saw blade, one piece of whiteware, one thick brown glass bottle base, and one worked chert flake. No subsurface artifacts were encountered at the site. Due to the previous disturbance of the site from pipelines and erosion and lack of subsurface artifacts, the resource was considered by Horizon to possess little research value and no further work was recommended. In 2012, the resource was determined ineligible for the NRHP within the ROW (THC 2019).

The portion of APE, Permit Area Number 79, that passes the previously recorded location of Resource 41 ER50 was surveyed by Gray \& Pape on April 5, 2019. The APE at the location measures approximately 40 meters (131 feet) wide, of which about 20 meters (66 
REMOVED FROM PUBLIC COPY

Plan view of Resource 41 ER49. 
feet) is within an existing pipeline ROW. The ROW is covered by short grass allowing good surface visibility. The remainder of the APE to the south contains scattered trees and grass but still offers good surface visibility (Figure 518). The site is located approximately 45 meters (148 feet) north of the current APE at Permit Area 79. At least five existing pipelines and a transmission corridor are located between the previously recorded site and the current APE.

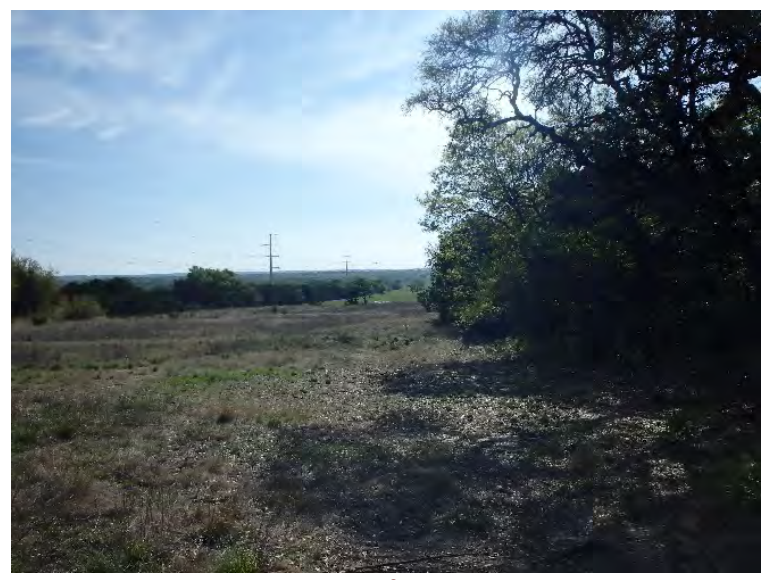

Figure 5-18. Overview of the APE where it passes near the previously recorded location of Resource 41 ER50. View is to the east.

The APE at the location was investigated by pedestrian survey and shovel testing with tests spaced between 30 and 40 meters (66 to 100 feet) apart (Figure 5-19). No artifacts were observed on the surface at the location. Of six shovel tests placed within the APE, none were positive for cultural materials. Soils mapped for the location consists of Purves-Maloterre association (NRCS 2019). Purves and Maloterre soils are all very shallow and encounter coarsely fractured indurated limestone bedrock at roughly 30 to 36 centimeters (12 to 14 inches) deep. Shovel tests at the location contained mottled dark grayish brown (1OYR 4/2) and reddish brown $2.5 Y R \quad 4 / 3$ silty clay.

No portion of the previously recorded resource appears to be located within the current APE and no further work is recommended for the location.

\subsubsection{Resource 41ER56}

Resource 41 ER56 was identified by Horizon in 2011 as part of the CREZ Lone Star Transmission Line Project (Cochran et al. 2012). The site was recorded as a multicomponent scatter of prehistoric and historic materials. The site is located approximately 650 meters ( 0.4 miles) south of the intersection of CR 242 and CR 376 in Erath County. The site is located in gently rolling pastureland on a south and southeast trending slope towards Cat Branch, which lies approximately 700 meters $(0.4$ miles) to the south. According to the site record, observed surface materials consist of one chert tertiary flake, one chert tool fragment, and four plus pieces of whiteware belonging to the same object. No subsurface artifacts were encountered at the site. Due to the previous disturbance of the site from pipelines and erosion and lack of subsurface artifacts, the resource was considered by Horizon to possess little research value and no further work was recommended. In 2012 the resource was determined ineligible for the NRHP within the ROW (THC 2019).

The portion of APE, Permit Area Numbers 48 and 49, where it passes the previously recorded location of Resource 41 ER56 was surveyed by Gray \& Pape on May 1, 2019. The APE at the location measures between 45 meters (148 feet) at the narrowest and 100 meters (328 feet) at the widest. Practically all of that area is within previously disturbed ROW or ROW workspace. A portion of the APE is also a fallow ag field/pasture covered by grasses, offering poor surface visibility (Figure 5-20). The remainder of the APE is covered by grass and shrubs offering low surface visibility. The site is located approximately 45 meters (148 feet) north of the current APE. At least six existing pipelines are located between the previously recorded site and the current APE. 
REMOVED FROM PUBLIC COPY

Plan view of Resource 41ER50. 


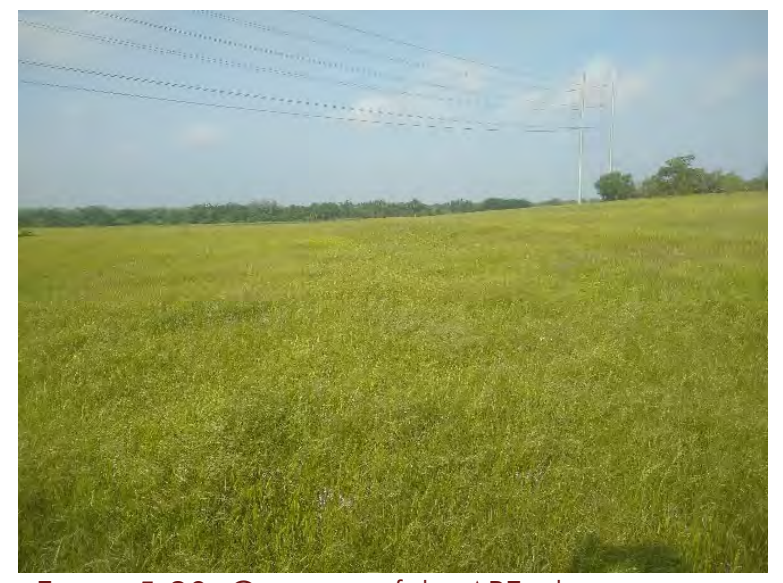

Figure 5-20. Overview of the APE where it passes near the previously recorded location of Resource $41 E R 56$. View is to the west.

The APE was investigated by pedestrian survey and shovel testing with tests spaced between 40 and 45 meters (131 and 148 feet) apart (Figure 5-21). No artifacts were observed on the surface within the APE. Of seven shovel closest tests placed within the APE at the location, none were positive for cultural materials. Soils mapped for the location consist of Windthorst fine sandy loam, 1 to 8 percent slopes, severely eroded (NRCS 2019). These soils are characterized by a shallow $A$ horizon of grayish brown (10YR 5/2) very fine sandy loam to a depth of 10 centimeters (4 inches). This is followed an $E$ horizon of light yellowish brown (10YR 6/4) very fine sandy loam. Below that are several $B$ horizons of red (2.5YR 4/6), yellowish red (5YR 5/6), and mottled brownish yellow (10YR 6/6) and strong brown (7.5YR 5/6) sandy clay down to 1 meter (39 inches) below surface (NRCS 2019).

Shovel tests at the location typically contained mottled dark grayish brown (1OYR 3/3) silty loam followed by strong brown (7.5YR 4/6) silty clay loam (Appendix C). The APE at the location consists almost entirely of previous workspace and/or plowed agricultural field. No portion of the previously recorded resource appears to be located within the current APE and no further work is recommended for the location.

\subsubsection{Deep Test Results}

Fieldwork at Alarm Creek was conducted on August 7, 2019. The location was originally surveyed as Permit Area 65; however, the location is slated for horizontal directional drill, and thus may eventually be removed from permitting. The permit area as currently identified subsumes approximately 1.9 hectares (4.6 acres) and is located right off of CR 246 approximately 12.9 kilometers (8 miles) south-southeast of Stephenville, Texas. The location is only 1.21 kilometers $(0.75$ miles) north of the confluence of Alarm Creek with the Bosque River. The APE at the location measures between 40 and 55 meters (131 and 180 feet) wide. Most of that width is within an existing pipeline ROW. The location consists of two separate field conditions. To the east/south of Alarm Creek and CR 246 is an agricultural field that at the time of the deep testing had been recently harvested (Figure 522). To the west/north of Alarm Creek was a grass and shrub covered pasture (Figure 523).

Soils mapped in this area consist of Wise clay loam, 3 to 5 percent slopes, moderately eroded (BcC2), Frio clay loam, occasionally flooded (Fr), and Bosque loam, occasionally flooded (Bo) (Soil Survey Staff, Natural Resources Conservation Service, United States Department of Agriculture (NRCS 2019). All three are soil series are deep and well drained soils that could contain A horizons beyond the reach of shovel testing.

Wise series soils are very deep, well drained, moderately permeable inceptisols. They are located on uplands and on low hills and formed in loamy and shaley marine sediments of lower Cretaceous Age. A typical soil profile consists of four strata (A-Bw-Bk-C) to a depth of 152.4 centimeters (60 inches). Soil profiles generally consist of a surface (A horizon) of brown (10YR 5/3) clay loam to a depth of 18 centimeters ( 7 inches). 
REMOVED FROM PUBLIC COPY

Plan view of Resource 41 ER56. 


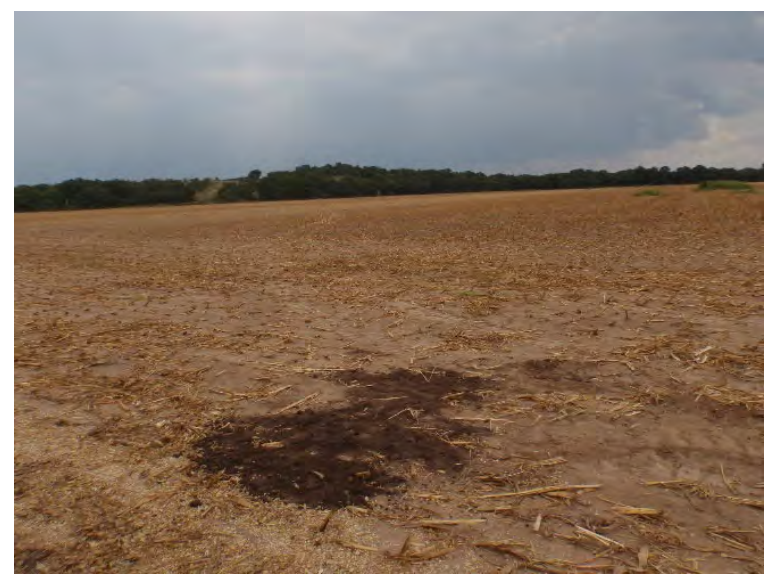

Figure 5-22. Overview of a harvested ag field south of Alarm Creek and CR 246. View is to the southeast.

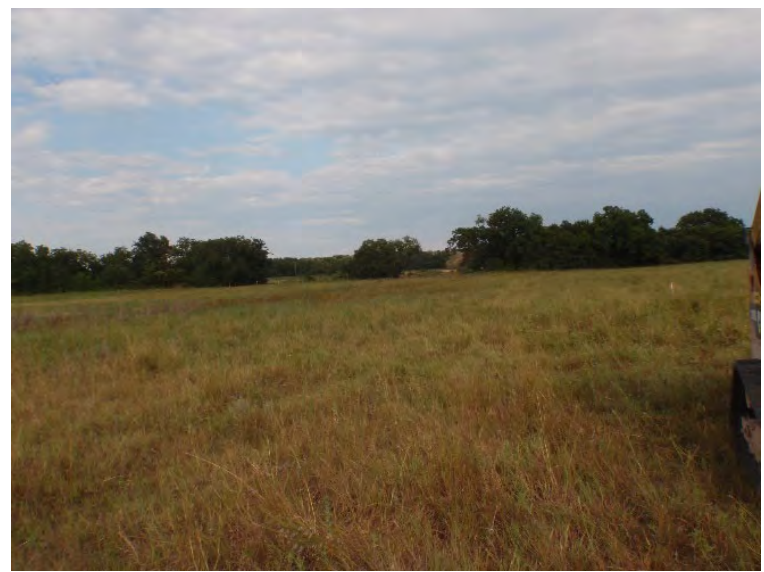

Figure 5-23. Overview of deep test locations to the west/north of Alarm Creek. View is to the northwest.

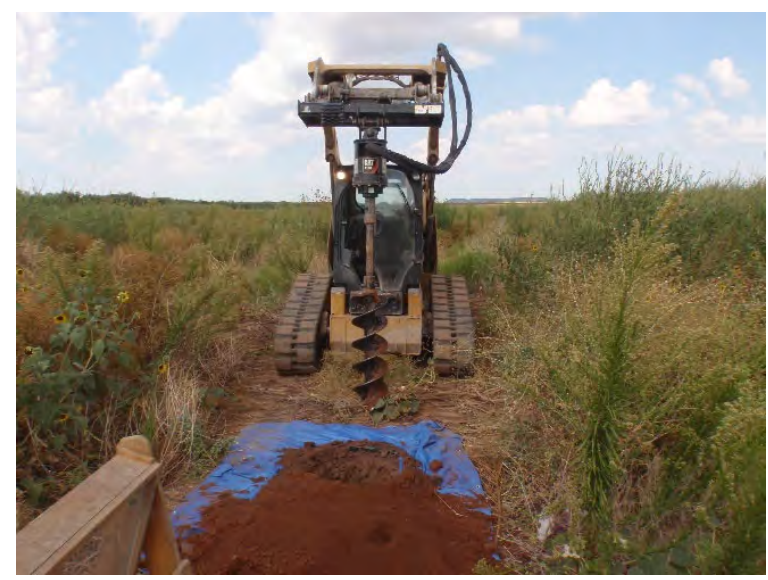

Figure 5-24. Bobcat equipped with an auger bit for deep testing. View is to the northwest.
That is followed by a successive subsoil layers (Bw-Bk horizons) of light brownish gray (2.5Y $6 / 2$ ) clay loam to a depth of 69 centimeters (27 inches). Below that is a substratum (C horizon) of stratified light gray (2.5Y 7/2) silt loam and light gray (5Y 7/2) shaley silty clay loam (NRCS 2019).

Frio series soils are very deep, well drained, moderately slowly permeable mollisols. They are located on nearly level flood plains and formed in calcareous loamy and clayey alluvium. A typical soil profile consists of five strata (A1-A2-A3-A4-Bk) that extend to 203 centimeters ( 80 inches) below the surface. Soil profiles generally consist of a surface (A) horizon) of dark grayish brown (10YR 4/2) silty clay to a depth of 20 centimeters (8 inches). That is followed by successive subsurface (A2A4 horizons) layers of dark grayish brown (10YR 4/2) clay loam and silty clay loam to a depth of 102 centimeters (40 inches). A subsoil layer (Bk horizon) of grayish brown (10YR 5/2) silty clay to a depth of 203 centimeters (80 inches) finishes out the profile (NRCS 2019).

Bosque series soils consist of very deep to loamy alluvium, well drained mollisols. These nearly level soils are located on treads of flood plains and formed in loamy, calcareous alluvium of Pleistocene age derived from limestone and shale. A typical soil profile consists of five strata (Ap-A1-A2-Bw-Akb) to a depth of 152 centimeters (60 inches). Soil profiles generally consist of a plowed surface (Ap horizon) of dark grayish brown (1OYR 4/2) loam to a depth of 13 centimeters (5 inches). That is followed by a subsurface (A1-A2 horizons) of dark grayish brown (10YR 4/2) loam / clay loam to a depth of 97 centimeters (38 inches). Below that is a subsoil (Bw horizon) of brown (10YR 5/3) clay loam to 127 centimeters (50 inches) depth. A buried surface (Akb horizon) of dark grayish brown (1OYR 4/2) clay finishes out the profile to a depth of 152 centimeters (60 inches) (NRCS 2019). 
At least one shovel test at the location contained soils that could represent deep alluvial material (Appendix C). Shovel Test $\mathrm{dd} 2$, contained a layer of light yellowish brown (10YR 6/4) sandy loam that continued to the limits of the shovel test at 1 meter (39 inches). The location was recommended for deep testing by the Field Archaeologist. This recommendation in tandem with the geomorphological data mapped for the location resulted in the area being deep tested.

Field investigations consisted of mechanical deep testing by means of an auger bit attached to a Bobcat (Figure 5-24). Investigation consisted of 8 auger tests measuring 38.1 centimeters (15 inches) in diameter (Figure 525 and 5-26). Because the proposed centerline is located between existing pipelines within the existing ROW, the tests were performed near the southern edge of the APE away from the existing ROW out of safety concerns.

A typical deep test profile (Table 5-13) within the permit area consists of a surface layer of pale brown (10YR 6/3) fine sandy loam to an average depth of 55 centimeters (21.65 inches) followed by light brownish gray (10YR 6/2) to light yellowish brown (10YR 6/4) sandy clay or sandy clay loam extending to an average depth of 115 centimeters (45.28 inches) underlain by dark gray (10YR 4/1) to brown (1OYR 4/3) clay loam or silty clay loam to an average depth of 170 centimeters (66.93 inches) (Figure 5-26). Finally, in some areas there is a fourth stratum of grayish brown (10YR 5/2) fine sandy clay or silty clay to the base of excavation at 180 centimeters (70.87 inches) below surface.

The lighter Munsell colors identified in the deep tests do not appear to represent either the Bosque or Frio series. They are within the range of the $\mathrm{Bw}$ horizon of the Bosque series however this would suggest the soils have been severely truncated. Some erosion would not be unusual for an area that has been impacted by agriculture and previous pipelines, but the amount of material that would need to have been removed would approximate 1 meter (39 inches) in depth. More likely, the soils represent the $B$ horizons of the Wise series, which entail a similar color clay loam. In general, the soils became blockier beyond 50 centimeters (20 inches) depth, at which point they could no longer be screened but were hand sorted.

A review of historical aerial imagery of the location indicates the land west of the creek had been contoured prior to 1961 and the land east of the creek has been plowed since at least the same date. Darker soils are eventually observed in Stratum III in most tests, but this change is more likely the result of an increase in moisture as they displayed no indication of a buried $A$ horizon but retained the same blocky structure as the soils above.

None of the deep tests were positive for cultural materials. The location is planned for instalment by Horizontal Directional Drilling (HDD), which removes the chances of surface or near surface impacts at the location. Further, the proposed centerline is to be installed within the existing ROW between two existing pipelines. These facts together suggest it is highly unlikely that the Project will impact intact buried cultural resources at Alarm Creek.

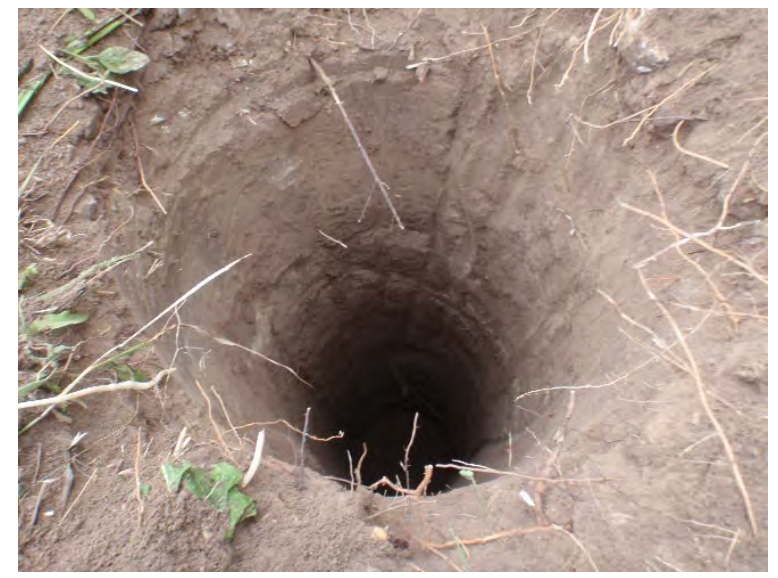

Figure 5-25. Representative soil profile as observed in Deep Test 1 at Alarm Creek. 
REMOVED FROM PUBLIC COPY

Deep test locations within Permit Area 65 at Alarm Creek. 
Table 5-13. Deep Test Profiles from the Project Area at Alarm Creek.

\begin{tabular}{|c|c|c|c|c|c|c|c|c|c|c|c|c|c|c|c|}
\hline Number & Creek & $\begin{array}{l}\text { Survey } \\
\text { Result }\end{array}$ & $\begin{array}{l}\text { Strat I } \\
\text { Depth }\end{array}$ & $\begin{array}{c}\text { Strat I } \\
\text { Munsell }\end{array}$ & $\begin{array}{l}\text { Strat I } \\
\text { Texture }\end{array}$ & $\begin{array}{l}\text { Strat II } \\
\text { Depth }\end{array}$ & $\begin{array}{c}\text { Strat II } \\
\text { Munsell } \\
\end{array}$ & $\begin{array}{l}\text { Strat II } \\
\text { Texture }\end{array}$ & $\begin{array}{l}\text { Strat III } \\
\text { Depth }\end{array}$ & $\begin{array}{c}\text { Strat III } \\
\text { Munsell } \\
\end{array}$ & $\begin{array}{l}\text { Strat III } \\
\text { Texture }\end{array}$ & $\begin{array}{l}\text { Strat IV } \\
\text { Depth }\end{array}$ & $\begin{array}{l}\text { Strat IV } \\
\text { Munsell }\end{array}$ & $\begin{array}{l}\text { Strat IV } \\
\text { Texture }\end{array}$ & Comment \\
\hline DTl & Alarm & Negative & 45 & 10YR 6/3 & Fine SaLo & 120 & 7.5YR 5/2 & SaClLo & 160 & 7.5YR 4/1 & ClLo & 180 & 10YR 5/2 & Fine $\mathrm{SaCl}$ & - \\
\hline DT2 & Alarm & Negative & 43 & $10 Y R 4 / 3$ & SaLo & 110 & $10 Y R 6 / 3$ & $\mathrm{SaCl}$ & 180 & 10YR 4/1 & ClLo & - & - & - & - \\
\hline DT3 & Alarm & Negative & 60 & 10YR $7 / 3$ & Fine SaLo & 110 & 10YR $6 / 4$ & SaClLo & 160 & 1OYR 4/1 & ClLo & 180 & 7.5 YR $5 / 2$ & $\mathrm{SiCl}$ & Caliche in Stratum III \\
\hline DT4 & Alarm & Negative & 40 & 10YR 4/3 & Fine SaLo & 105 & 10YR 6/4 & SaClLo & 170 & 10YR 5/3 & $\mathrm{SaCl}$ & - & - & - & - \\
\hline DT5 & Alarm & Negative & 70 & 10YR 6/3 & Fine SaLo & 115 & 10YR 6/2 & Fine SaClLo & 180 & 10YR 4/3 & $\mathrm{SiCl}$ & - & - & - & - \\
\hline DT6 & Alarm & Negative & 60 & $10 Y R 6 / 3$ & Fine SaLo & 120 & 10YR $6 / 2$ & Fine SaClLo & 180 & $7.5 Y R 4 / 1$ & $\mathrm{SiCl}$ & - & - & - & - \\
\hline DT7 & Alarm & Negative & 60 & 10YR 6/3 & SaClLo & 115 & $7.5 Y R \quad 4 / 3$ & Fine SaLo & 180 & $7.5 Y R 3 / 3$ & $\mathrm{SiCl}$ & - & - & - & $\begin{array}{c}\text { Caliche and chert gravels in } \\
\text { Strata II and III }\end{array}$ \\
\hline DT8 & Alarm & Negative & 60 & 10YR 6/3 & SaClLo & 115 & 7.5YR $4 / 3$ & Fine SaLo & 180 & 7.5YR $3 / 3$ & $\mathrm{SiCl}$ & - & - & - & $\begin{array}{c}\text { Caliche and chert gravels in } \\
\text { Strata II and III }\end{array}$ \\
\hline
\end{tabular}




\subsection{CONCLUSIONS AND RECOMMENDATIONS}

This report details the results of pedestrian cultural resources survey of permit areas within 142.27 kilometers (88.4 miles) of the Lone Star Express II Pipeline Project - Loop 3 in Eastland, Comanche, Erath, and Bosque Counties, Texas. The lead agency for the Project is the USACE, Fort Worth District. Nearly all of the Project will be installed by open trench; however, the location at Alarm Creek is currently planned for HDD.

A records and literature review initiated prior to survey identified one previously recorded archaeological resource potentially intersecting USACE permit areas within Loop 3. Fieldwork on Loop 3 was conducted by Gray \& Pape in the Spring 2019 and required approximately 3,680-person hours to complete and involved archaeological reconnaissance and shovel testing throughout anticipated permit areas within the Project corridor.

A total of 124 permit areas were surveyed, encapsulating a total of 52.8 kilometers (32.8 miles) of centerline and 209.9 hectares (518.6 acres) of APE. In total, approximately 871 shovel tests were excavated within permit areas, four of which were positive for cultural materials. No evidence was identified within the APE of four previously recorded resources located within 91 meters (300 feet) of the APE. Two new previously unrecorded resources, 41BQ358 and 41BQ359, and one isolate find were identified. No evidence was identified for previously recorded Resource
41ER48 within the APE. Likewise, no evidence was identified for resources 41ER49, 41ER50, or 41ER56 within portions of APE that were located within 91 meters (300 feet).

Both identified sites consist of small lithic scatters and are considered ineligible (Table 61). The resource areas showed clear disturbance from previous impacts associated with the pipeline ROW, impacts from agriculture in the case of $41 B Q 359$, and soil deflation. Resource 41BQ358 and Isolate BQ07-ISO-01 are also spatially limited by the natural topography of the area. Neither of the lithic scatters contained temporally or culturally diagnostic prehistoric artifacts and no artifacts were collected. These largely were represented by surface scatters of lithics which are typical for the area and were consistent with the resources identified within jurisdictional permit areas. Observance of these resources within the APE indicated no features or diagnostic artifacts and suggests research potential is low. Revisions to the workspace at Resource $41 \mathrm{BQ} 359$ will avoid the site, removing it from permitting, and the section of workspace that passes the resource will be marked by orange fencing. None of these resources are recommended as eligible within the APE and no further work is recommended regarding them (Table 6-1). The lone diagnostic artifact, Isolate BQ-07-ISO-01, consists of an Ellis or Godley type projectile point dating to the Late to Transitional Archaic.

Table 6-1. Summary of Resources Identified within the APE.

\begin{tabular}{|c|c|c|c|c|c|}
\hline Trinomial & Jurisdictional? & Site Type & Temporal Affiliation & $\begin{array}{c}\text { Research } \\
\text { Value }\end{array}$ & $\begin{array}{c}\text { NRHP } \\
\text { Recommendation }\end{array}$ \\
\hline 41BQ358 & Yes & $\begin{array}{c}\text { Prehistoric Lithic } \\
\text { Scatter }\end{array}$ & Unspecified Prehistoric & Low & Not eligible \\
\hline $\begin{array}{c}\text { BQ-07-ISO- } \\
\text { 001 }\end{array}$ & Yes & Prehistoric Isolate & Late to Transitional Archaic & Low & Not eligible \\
\hline 41BQ359 & No & $\begin{array}{c}\text { Prehistoric Lithic } \\
\text { Scatter }\end{array}$ & Unspecified Prehistoric & Low & Not eligible \\
\hline
\end{tabular}


One location, Alarm Creek, was investigated by mechanical auguring to determine if the location contained soils with A horizons deeper than can be reached by shovel or deeply buried cultural materials or paleosols. However, deep testing within the APE at the location displayed a surface and subsurface that likely represents the $B$ horizon of the Wise series and produced no evidence for deeply buried resources or buried paleosols at the location. Further, the location is planned for Project installation by means of HDD.

While the identification of the observed resources adds to the overall knowledge base of the region, the paucity of artifacts, lack of diagnostic materials within context, fragmentary nature of the artifacts, and lack of integrity, suggests that these resources do not have the potential to add further insight on prehistoric or historic occupation in the region. Based on current data, the resources are recommended not eligible for listing in the NRHP according to Criteria A through D. Gray \& Pape currently recommends no additional archaeological work for any portions of Project corridor surveyed. However, Gray \& Pape recommends that an unanticipated discoveries plan be put into place in the event that such discoveries take place during construction. 


\subsection{REFERENCES CITED}

Antevs, Ernst

1954 Climate of New Mexico During the Last Glacio-Pluvial, Journal of Geology 62.2, pp. 182-191.

Barnes, Virgil

1967 Bureau of Economic Geology, Sherman Sheet, Geologic Atlas of Texas: University of Texas at Austin, Bureau of Economic Geology, scale 1:250,000.

1977 Bureau of Economic Geology, Clovis Sheet, Geologic Atlas of Texas, Bureau of Economic Geology, University of Texas at Austin, scale 1:250,000.

1983 Bureau of Economic Geology, Tucumcari Sheet, Geologic Atlas of Texas, Bureau of Economic Geology, University of Texas at Austin, scale 1:250,000.

Bureau of Economic Geology (BEG)

1996 Physiographic Map of Texas. The University of Texas at Austin.

2000 Vegetation/Cover Types of Texas. The University of Texas at Austin.

2008 General soil Map of Texas. The University of Texas at Austin.

Cochran, Jennifer L., Jeffery D. Owens, Russell K. Brownlow, and Reymundo Chapa

2012 Cultural Resources Investigations along the Proposed Lone Star Competitive Renewable Energy Zone (CREZ) 345-kV Transmission Line Right-of-Way in North-Central Texas. Volumes I and II. Report produced by Horizon Environmental Services, Inc. Austin, Texas.

Ferring, C. Reid

2007The Geology of Texas. Thompson Corporation, Stamford.

Frison, G.C.

1991 The Goshen Paleoindian Complex: New Data for Paleoindian Research. In Clovis and Adaptations, edited by R. Bonnichsen and K.L. Turnmire. Center for the Study of the First Americans, University of Maine, Orono.

Griffith, Glenn, Sandy Bryce, James Omernik, and Anne Rogers

2007 Ecoregions of Texas. Dynamac Corporation, Corvallis.

Haley, James L.

2010 Red River War. Handbook of Texas Online. http://www.tshaonline.org/handbook/online/articles/qdrO2. Accessed March 2019.

Hofman, Jack L.

1989 Prehistoric Culture History $\neg$-Hunters and Gatherers in the Southern Great Plains. In From Clovis to Comanchero: Archaeological Overview of the Southern Great Plains, by Jack L. Hofman, Robert L. Brooks, Joe S. Hayes, and Douglas W. Owsley, Richard L. Jantz, Murray K. Marks, and Mary H. Manheim. Research Series No. 35. Arkansas Archaeological Survey, Fayetteville. 
Holliday, V.T.

1997 Paleoindian Geoarchaeology of the Southern High Plains. University of Texas Press, Austin.

Hughes, Jack T.

1991 Prehistoric Developments on the Texas High Plains. Bulletin of the Texas Archeological Society, 60, pp. 1-56.

1962 Lake Creek: A Woodland Site in the Texas Panhandle. Bulletin of the Texas Archeological Society, 32, pp. 65-84.

Johnson, Eileen and Vance T. Holliday

2004 Archeology and Late Quaternary Environments of the Southern High Plains. In The Prehistory of Texas, Edited by Timothy K. Perttula. Texas A\&M University Press, College Station.

Kelley, Jane Holden

1964 Comments on the Archeology of the Llano Estacado. Bulletin of the Texas Archeological Society, 35, pp. 1-18.

Lowther, A.C.

1981 Soil Survey of Nolan County, Texas. United States Department of Agriculture, Soil Conservation Service.

Meltzer, D.J.

1987 The Clovis Paleoindian Occupation of Texas: Results of the Texas Clovis Fluted Point Survey. Bulletin of the Texas Archeological Society 57:27-68.

Munsell Soil Color Chart (Munsell)

2005 Revised Edition. Macbeth Division of Kollmorgan Instruments Corporation.

Newcomb, W.W.

1961 The Indians of Texas: from Prehistoric to Modern Times. University of Texas Press, Austin.

Perttula, Timothy K. (editor)

2004 The Prehistory of Texas. Texas A \& M University Press, College Station.

Prikryl, D.J.

1990 Lower Elm Fork Prehistory: A Redefinition of Cultural Concepts and Chronologies along the Trinity River, North-central Texas. Report No.37. Austin: Office of the State Archeologist, Texas Historical Commission.

Soil Survey Staff, Natural Resources Conservation Service, United States Department of Agriculture (SSS NRCS USDA)

2018 Web Soil Survey. Available URL:

http://websoilsurvey.nrcs.usda.gov/app/WebSoilSurvey.aspx. Accessed March, 2019.

Stringer, Billy R.

1980 Soil Survey of Bosque County, Texas. United States Department of Agriculture, Soil Conservation Service. 
Turner, Ellen Sue and Thomas R. Hester

1993 A Field Guide to Stone Artifacts of Texas Indians. Second Edition. Texas Monthly Field Guide Series, Gulf Publishing Company, Houston.

Turner, Ellen Sue, Thomas R. Hester, and Richard L. McReynolds 2011 Stone Artifacts of Texas Indians. Taylor Trade Publishing, Plymouth, United Kingdom.

United States Department of Agriculture - Natural Resources Conservation Service, Soil Survey Office (USDA-NRCS, SSO)

2008 General Soil Map of Texas. https://legacy.lib.utexas.edu/maps/texas/texasgeneral_soil_map-2008.pdf. Accessed March 2019.

Wagner, Billy J., et al.

1977 Soil Survey of Erath County, Texas. United States Department of Agriculture, Soil Conservation Service.

Willey, Patrick S. and Jack T. Hughes

1978 The Deadman's Terrace Site, Archeology at MacKenzie Reservoir. Archeological Survey Report 24. Office of the State Archeologist, Texas Historical Commission, Austin.

Wormington, H.M.

1957 Ancient Man in North America. Popular Series, 4th Ed., Denver: Denver Museum of Natural History.

Wheat, Joe Ben

1972 The Olson-Chubbuck Site. A Paleo-Indian Bison Kill. Memoirs 26. Society for American Archeology, Washington, D.C.

Whitlock, V.H.

1970 Cowboy Life on the Llano Estacado. University of Oklahoma Press, Norman.

Young, Dan M.

2017 Handbook of Texas Online, Young, "ERATH COUNTY," accessed May 13, 2019, http://www.tshaonline.org/handbook/online/articles/hce06. Uploaded on June 12, 2010. Modified on August 24, 2017. Published by the Texas State Historical Association. 


\section{APPENDIX A: PERMIT AREAS WITHIN THE LOOP 3 ALIGNMENT.}

\section{REMOVED FROM PUBLIC COPY}




\section{APPENDIX B: FIELD RESULTS WITHIN PERMIT AREAS ALONG THE PROPOSED LOOP 3 PROJECT ALIGNMENT.

\author{
REMOVED FROM PUBLIC COPY
}


APPENDIX C: SHOVEL TEST LOG.

\author{
REMOVED FROM PUBLIC COPY
}

